$1-1-1942$

\title{
Some physical and chemical properties of the principal orchard soils in the eastern panhandle of West Virginia
}

\author{
G. M. Browning \\ R. H. Sudds
}

Follow this and additional works at: https://researchrepository.wvu.edu/ wv_agricultural_and_forestry_experiment_station_bulletins

\section{Digital Commons Citation}

Browning, G. M. and Sudds, R. H., "Some physical and chemical properties of the principal orchard soils in the eastern panhandle of West Virginia" (1942). West Virginia Agricultural and Forestry Experiment Station Bulletins. 303.

https://researchrepository.wvu.edu/wv_agricultural_and_forestry_experiment_station_bulletins/304 @ WVU. It has been accepted for inclusion in West Virginia Agricultural and Forestry Experiment Station Bulletins by an authorized administrator of The Research Repository @ WVU. For more information, please contact ian.harmon@mail.wvu.edu. 
West Virginia University Libraries

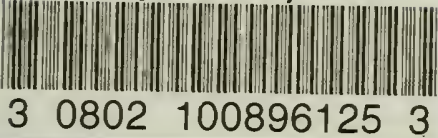





\section{Some Physical and Chemical Properties of the Principal Orchard Soils} in the Eastern Panhandle of West Virginia

by

G. M. Browning and R. H. Sudds

AGRICULTURAL EXPERIMENT STATION

COLLEGE OF AGRICULTURE, FORESTRY, AND HOME ECONOMICS WEST VIRGINIA UNIVERSITY

C. R. ORTON, Director MORGANTOWN 


\section{CONTENTS}

Introduction

Procedure

Brief Descriptions of the Major Orchard Soils in the Eastern Panhandle 7

Soils Derived from Sandstone or Shale or Both--

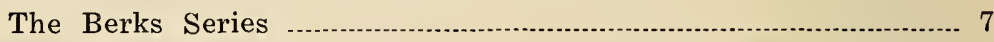

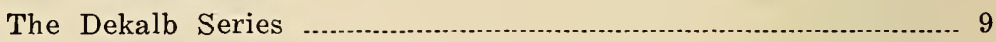

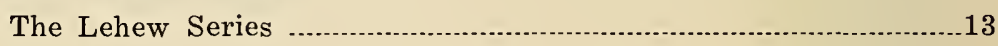

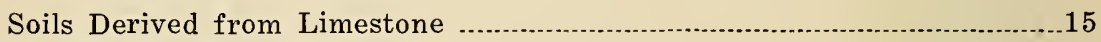

The Elliber Series ….............................................................15

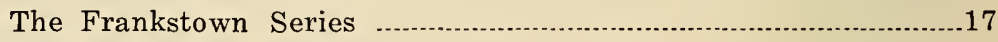

The Hagerstown Series .......................................................20

The Frederick Series .................................................................23

The Colbert Series …...............................................................24

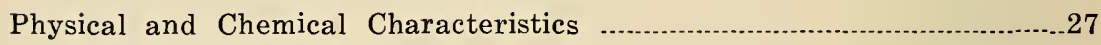

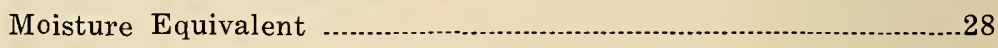

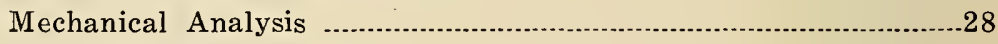

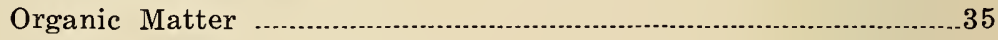

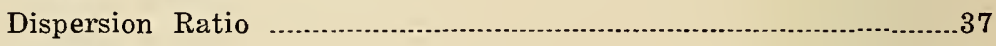

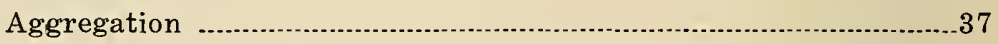

Supplemental Data on the Effect of Soil Management on Certain

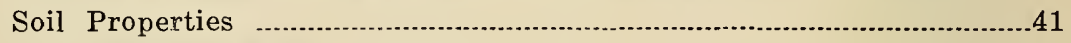

Volume Weight .......................................................................41

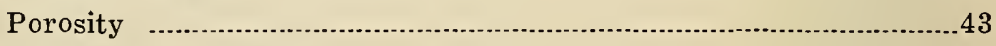

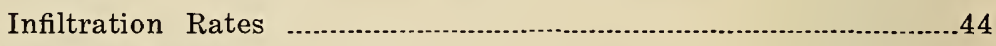

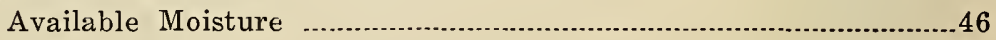

General Discussion ..............................................................................51

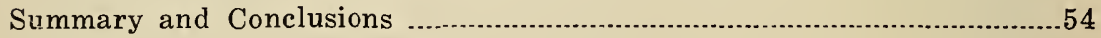

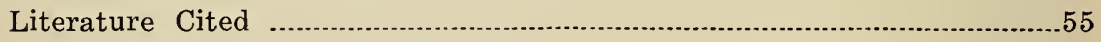




\title{
Some Physical and Chemical Properties of the Principal Orchard Soils in the Eastern
}

\section{Panhandle of West Virginia}

\author{
G. M. Browning * and R. H. Sudds $\dagger$
}

\section{INTRODUCTION}

$T^{\text {HE NATURE }}$ of the orchard soil, together with its efficient management and the desirability of the site on which that soil is situated, is becoming of increasing importance in the highly competitive business of modern fruit-growing. The economic success of the orchard is based to a large extent on yield; and that yield is an integration of many factors, foremost among them- site and soil.

The commercial apple- and peach-growing industry of West Virginia is located chiefly in the Eastern Panhandle, particularly in the counties of Berkeley, Jefferson, Hampshire, and to a considerably lesser extent in Morgan, Mineral, Hardy, and Grant. Some of these orchards return a net profit in all but an occasional season; a rare few show at least some net profit even in a bad year for marketing or for production. However, certain of these orchards may make money only in an exceedingly favorable season. Again, there may be those that probably never can make a positive net return no matter what occurs. How great a role does the soil play with these orchards?

This bulletin presents the results of a study of soil factors affecting apple-orchard economics in the Eastern Panhandle of West Virginia. Certain physical and chemical measurements of the properties of the soils studied in the course of this investigation are presented, together with explanations based on these data as to why one might expect a particular orchard soil or a soil property to affect its desirability for orcharding.

For this purpose, trenches were dug in commercial apple orchards on nearly all of the more important soil series; the depth and the vertical distribution of the tree roots were charted. The ability of the several soil series to take up water under various conditions of surface cover and of cultivation was

The services of Dillon S. Brown, Department of Horticulture, West Virginia Agricultural Experiment Station, in obtaining the soil samples are gratefully acknowledged.

*Soil Conservationist, Office of Research, Soil Conservation Service, U. S. Department of Agriculture, in cooperation with the West Virginia Agricultural Experiment Station.

tAssocfate Horticulturist, West Virginia Agricultural Experiment Station. 
studied. The amount of water available to the trees per foot of soil depth at the field capacity was determined for several of the soil series.

In so far as possible, all of the above factors are integrated as to their influence on what the growers desire most: the production, in as brief a period as is economically possible, of a tree with a size sufficient to produce regularly, during its long productive life in the orchard, the maximum yield of highlycolored and well-finished fruit.

\section{PROCEDURE}

The root-distribution charts and the soil-profile descriptions shown in this bulletin were adapted from field charts made by L. P. Batjer.* Trenches were dug in the Hagerstown, Frankstown, Elliber, Berks, Dekalb, and Lehew series representing every major orchard-soil series in the Eastern Panhandle except the Frederick. Representative apple trees, usually of the York Imperial variety, were selected in typical orchards situated on these soils. At a distance of 7 to 10 feet from the trunk, tangential excavations were made. The depths attained were commonly those of the deepest roots, except with the Hagerstown and the Frankstown series.

The faces of the excavations nearest the tree trunks were smoothed carefully; their surfaces were divided into a regular pattern of one-foot squares by means of nails and twine. The profile characteristics were noted and the distributions and sizes of the roots were plotted on cross-section paper. In these charts, as reproduced from the field sheets, the solid black dots represent roots with diameters up to $2 \mathrm{~mm}$. The smallest heavy circles indicate roots from 2 to $5 \mathrm{~mm}$, while the smallest light circles represent roots from 5 to $10 \mathrm{~mm}$. The next size of larger heavy circles shows roots from 10 to $20 \mathrm{~mm}$ in diameter and the largest light circles represent those roots of 20 $\mathrm{mm}$ and up.

The root-distribution charts show average conditions for the specific soils with only one exception-that of the Berks. An orchard, the most desirable on that soil in the Eastern Panhandle, was selected because the root-distribution charts showed how the trees on that series are handicapped at best.

Mechanical analyses were made according to the procedure outlined by Olmsted et al. (16). Aggregate distributions were determined by the method described by Yoder (26): the airdry soil was passed through a $7.0 \mathrm{~mm}$ screen, and the samples

*Formerly Assistant Horticulturist, West Virginia Agricultural Experiment Station. 
were allowed to slake 20 minutes on the screen before fractionation. Dispersion ratios were calculated by dividing the less than $0.05 \mathrm{~mm}$ fraction resulting from the aggregate analyses by the less than $0.05 \mathrm{~mm}$ fraction obtained after dispersion with sodium oxalate, then by multiplying the resultant decimal fraction by 100 :

Specific-gravity determinations were made by the method outlined by Hillebrand (14). A California soil tube (23) was used in collecting the soil samples for the volume-weight determinations. The samples were weighed, coated with paraffin of known volume weight, and re-weighed; finally the volume was determined by weighing in water.

Organic-matter determinations were made by a modification of the Schollenberger $(19,20)$ rapid-titration method essentially as described by Wakley and Black (25). The average amount of recovery by the dry-combustion and rapid-titration method was used as an approximate factor for correcting the values obtained for organic matter by the rapid-titration method (8).

Moisture equivalents were determined by using a laboratory centrifuge equipped with trunnion cups as described by Goldbeck and Jackson (13). The speed required to give a force of 1000 times gravity was controlled within 50 R.P.M. by use of an International centrifuge tachometer No. 78. Five grams of soil was weighed into Gooch crucibles fitted with filter papers, after which the procedure for saturating, draining, and centrifuging the sample was identical with that followed in determining the moisture equivalent by the Briggs-McLane method (1).

The moisture equivalent was used as a measure of capillary porosity and the non-capillary porosity was obtained by subtracting the moisture content by volume at the moisture equivalent from the total porosiy. The total porosity in percentage was calculated with the usual formula: $\frac{A-B}{A} \times 100$, where $\mathrm{A}=$ real specific gravity, and $\mathrm{B}=$ apparent specific gravity.

Infiltration rates were determined with the North Fork type (18) infiltrometer (Fig. 1). The calculated amount of water necessary to bring the soil to the field capacity was applied with a sprinkling can. After saturating, the plots were covered with burlap bags and allowed to stand 24 hours before using the infiltrometer. Determinations were made on three separate plots and their values were averaged for each soil series: the agreement between the three figures was generally very close. 


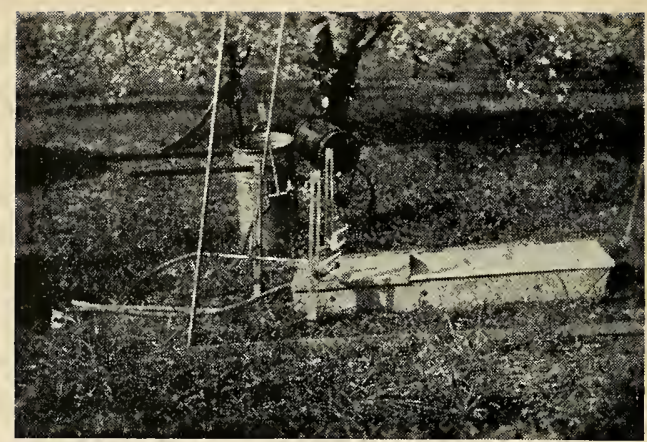

Fig. 1-North Fork infiltrometer with plot walls, run-off trough and cover, rain pan, support stakes, sprinkler head, and pump, in place ready for a calibration run except for the tent

In all cases, observations with the infiltrometer were made with the rain pan in place until the results of 3 successive oneminute periods checked within $5.0 \mathrm{cc}$. The rain pan was then removed and the water was allowed to fall on the $11 \times 30$-inch plot. Measurements of the run-off were recorded at frequent intervals until a 30-minute period was observed during which there was little or no change in its rate. In addition the total run-off was obtained for this 30 -minute period; then the rain pan was replaced, and three successive one-minute readings were taken. The infiltration rate was calculated in inches per hour by subtracting the rate of run-off from the soil from that of the rain pan. All plots possessed a slope of approximately six percent.

In using the infiltrometer the vegetation was clipped to a height of $1 / 2$ inch on the undisturbed plot area. The disturbed areas were cultivated with a hoe to a depth of 3 inches. A $11 / 2-$ inch layer of wheat straw was used in studying the effect of mulching on losses of soil and water. 


\section{BRIEF DESCRIPTIONS OF THE MAJOR ORCHARD SOILS IN THE EASTERN PANHANDLE}

\section{SOILS DERIVED FROM SANDSTONE OR SHALE OR BOTH*}

\section{The Berks Series}

The Berks series (Charts 1 and 2) occupies a prominent broad ridge extending in a northeasterly-southwesterly direction through the longitudinal axis of the Shenandoah Valley. This ridge is in general conspicuously higher in elevation than the adjoining limestone soil areas. There is an additional area of the Berks in the form of a relatively narrow band along the base of North Mountain, which marks the western edge of the valley.

\section{CHARTS OF VERTICAL DISTRIBUTION OF APPLE-TREE ROOTS}

Legend for all root-distribution charts: solid dots, roots with diameters up to $2 \mathrm{~mm}$; smallest heavy circles, roots from 2 to $5 \mathrm{~mm}$; smallest light circles, roots 5 to $10 \mathrm{~mm}$; largest heavy circles, roots from 10 to $20 \mathrm{~mm}$; largest light circles, roots of $20 \mathrm{~nm}$ in diameter and up.

The letters at the right side of each chart do not represent horizons but merely designate more or less distinct layers.

The data for these charts were obtained by means of tangential trenches about two feet wide and dug to the depths and lengths indicated. These trenches were from 7 to 10 feet from the tree trunks. The charts represent the trench faces proximal to the trees.

\section{FEET}

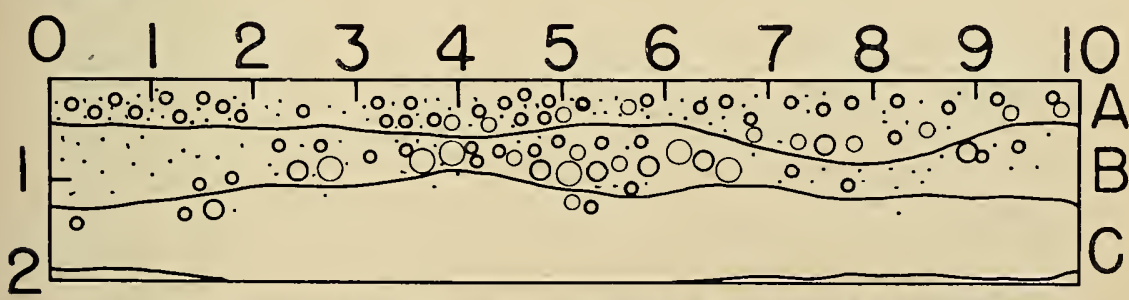

Chart 1 -Root distribution on the Berks silt loam, shallow phase

A, greyish brown silt loam containing numerous small fragments of shale; $B$, pale yellow compact silt loam with fragments of yellow and rusty brown shale; C, rusty brown and yellow shale and slate, this solid layer limits the depth of rooting.

The parent material of the Berks is chiefly non-calcareous shale. The topography is characteristically undulating to decidedly rolling, with occasional narrow, shallow stream valleys usually with steep slopes. Much of the Berks is steeply sloping. Probably most of the series averages less than 30 inches in depth

*The soil classification followed in this bulletin represents the work of $B$. $H$. Williams and A. T. Sweet of the Division of Soil Survey, Bureau of Plant Industry, U. S. Department of Agriculture. 


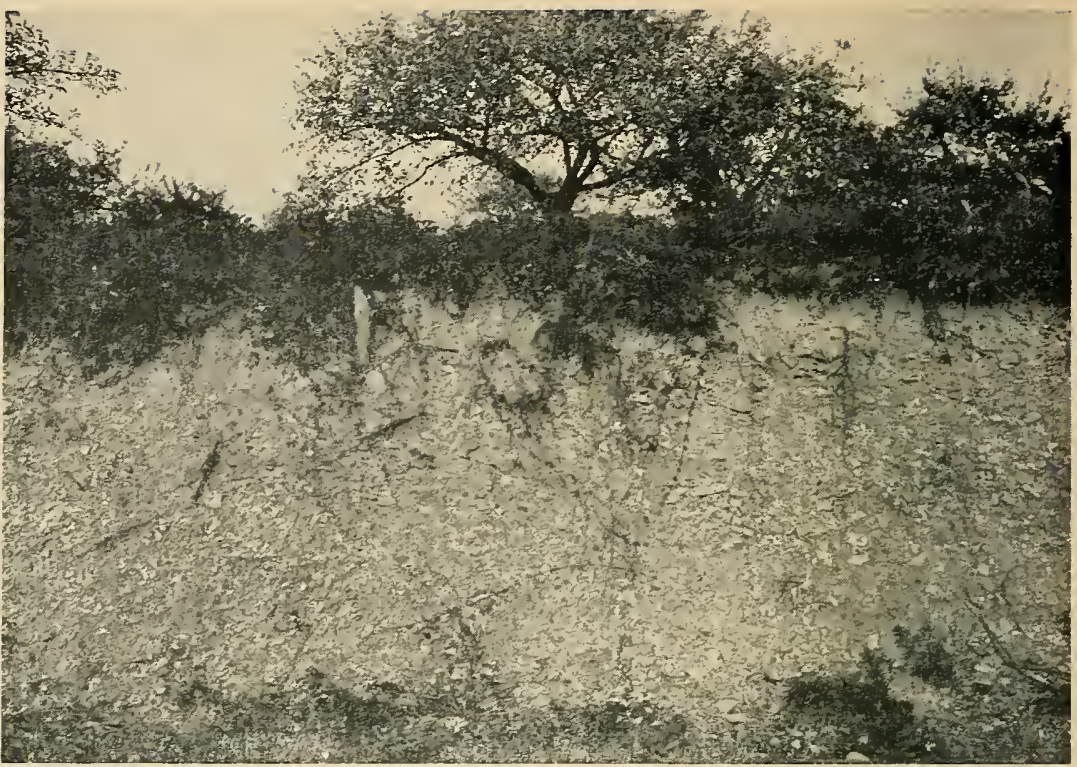

Fig. 2-Road-cut profile of the Berks. The dwarfed, mature apple tree is characteristic of those in the entire orchard, which was damaged severely in the drouth of 1930

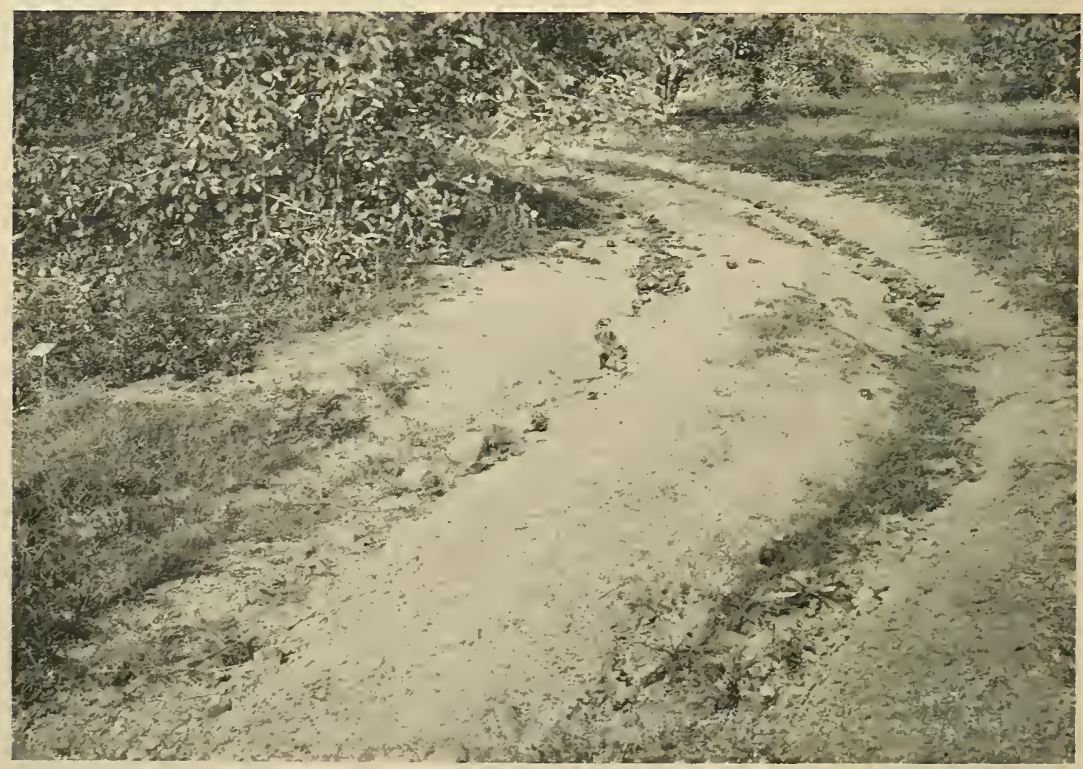

Fig. 3-An orchard road on the Berks. The wheel tracks erode typically with nearly vertical sides. They may become so deep that the axles and under-carriages of orchard machinery drag, thus forcing either extensive repairs or abandonment of the road 
to unbroken shale (Figs. 2 and 3) with somewhat deeper areas located on limited, relatively level, spots. The surface drainage is usually adequate to excessive, and the run-off invariably results in severe erosion of unprotected soils. The internal drainage is inclined to be poor; such is indicated by the conspicuous mottling.

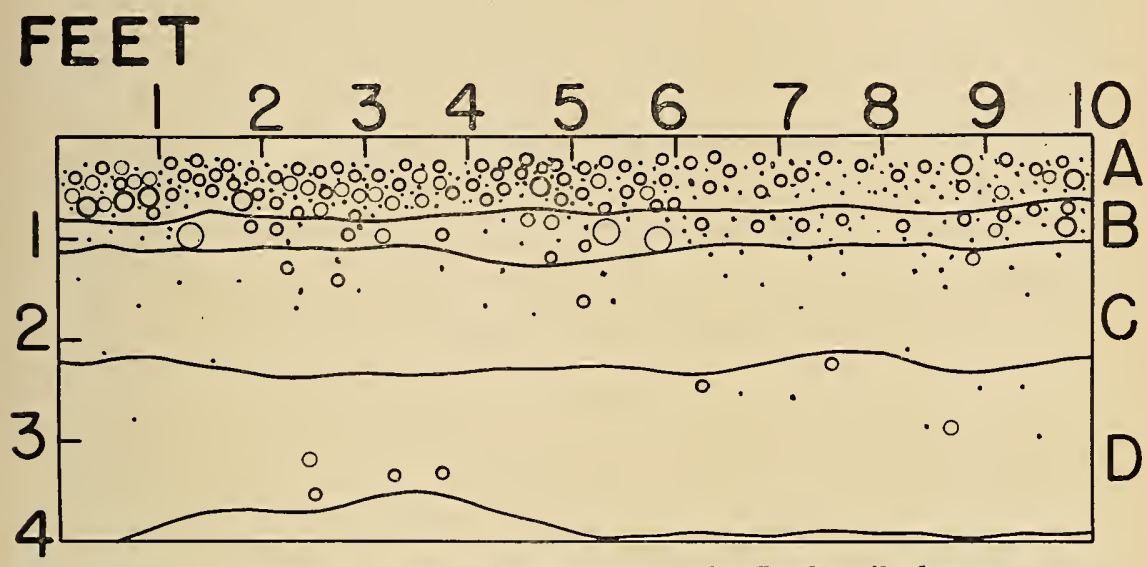

Chart 2-Root distribution on the Berks silt loam

A, light brown silt loam with numerous slate and shale fragments, firm but not compact; $B$, yellowish brown to pale greyish yellow silt loam with small shale fragments throughout, moderately compact; C, reddish brown silty clay loam with slight cleavage structure, breaks out into irregularly shaped clods, when compressed has slick shaly feel; D, orange, grey, yellow, and brown partially-weathered shale, laminated; grading into solid slate and shale which limits the depth of rooting.

The Berks series is almost exclusively of historical rather than of present importance. At the end of the 19th century, apple- and peach-growing were reported to be much more extensive on this series than on any of the other soils in West Virginia (9). Indeed, in 1902, the Berks was held to be "naturally best suited" for peach growing (10). However, before 1937, commercial fruit-growing had all but disappeared from the Berks. The drouth of 1930 was perhaps the chief factor responsible for this shift (Figure 2).

It is unquestionably true that, with the Berks, the available soil moisture reaches critical levels even during the usual dry periods in the growing season. In practically all of the commercial orchards situated in part on the Berks, it is usually possible to delimit the areas on that series by the smaller size and by the poorer average physical condition of the trees.

\section{The Dekalb Series}

The Dekalb is the most extensive soil series in the Eastern Panhandle. The parent materials are thin-bedded, rather finegrained sandstones and non-calcareous shales. A shale silt 
loam is the dominant type of this series; it covers the greater part of the low hills and valleys west of North Mountain. Chart 3 shows the vertical distribution of apple tree roots in the Dekalb shale silt loam. Chart 4 was obtained in an excavation on the Dekalb fine sandy loam, the lightest upland soil in the district.
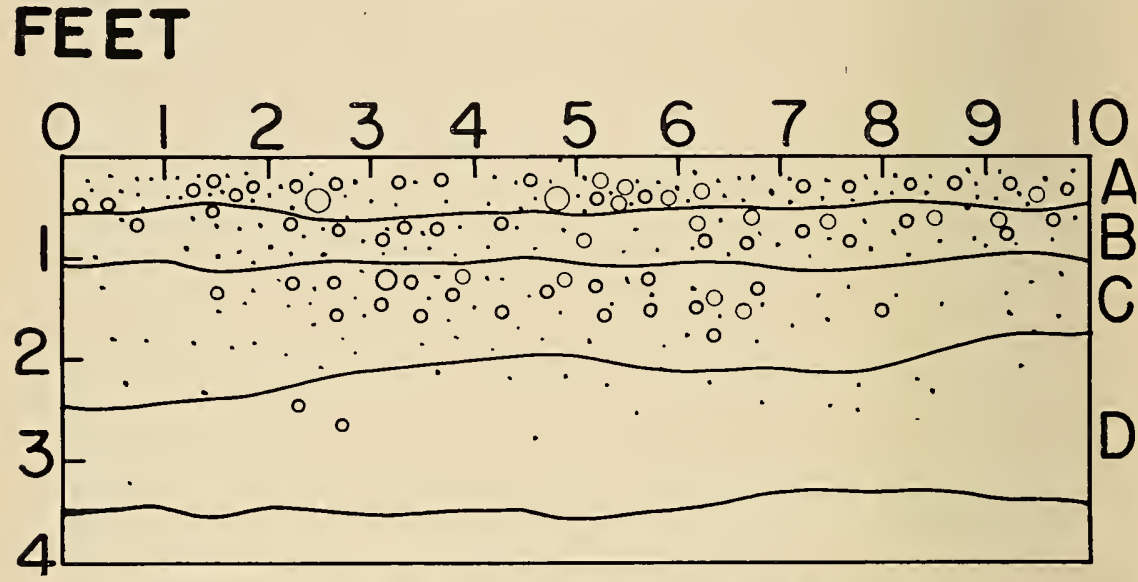

Chart 3-Root distribution on the Dekalb shale silt loam

A, brown, very fine sandy to silt loam, slate and shale fragments throughout; B, greyish yellow silt Ioam with reddish cast, numerous flat angular shale fragments; C, dull yellowish brown silt loam, gritty, some clay to make it hard and compact, cemented, shale fragments; D, yellow-brown sandstone and shale, solid, and limiting root penetration with an occasional root following a crevice.
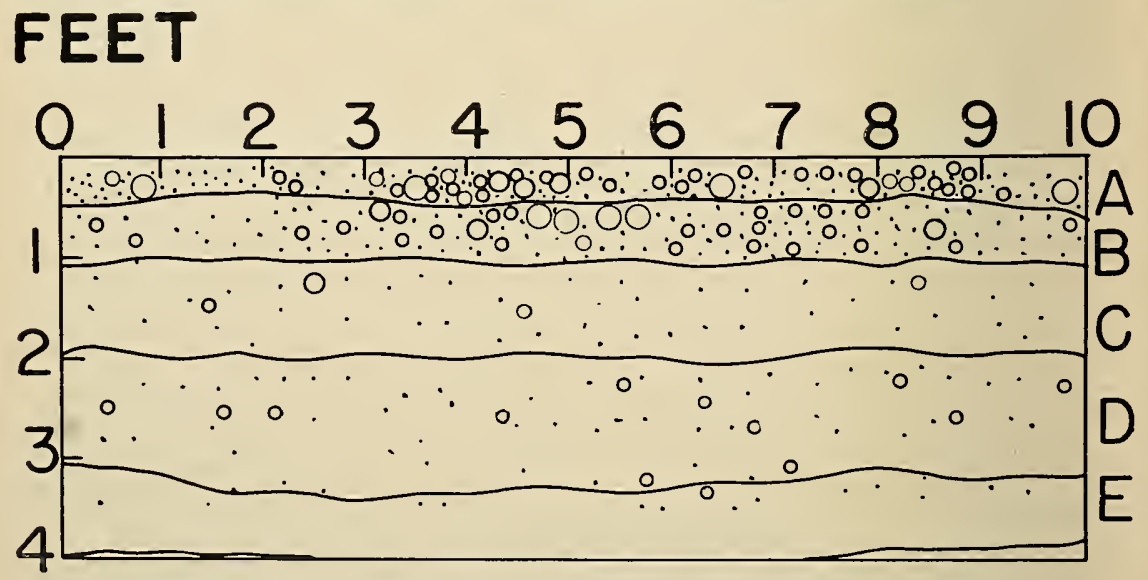

Chart 4-Root distribution on the Dekalb fine sandy loam

A, dark greyish brown, very fine sandy to silt loam, numerous soft sandstone shale of pea-to-nut size scattered through layer; $B$, olive-brown silt loam, loose and friable, some sandstone gravel; $C$, pinkish brown silt loam, practically the entire layer is made up of flat soft sandstone shale, very little soil present; $D$, reddish brown sandstone fragments with some soil mixed between, these stones are flat and angular and have somewhat of a mosaic structure, dovetailing into each other; E, soft sandstone-shale, no crevices, limiting the depth of root penetration. 
While in lack of depth the Dekalb approaches the Berks, the Dekalb is the superior soil for fruit growing because of its commonly greater depth, when the deeper areas are managed with due regard for the considerable limitations of this series. As with the Berks, the drouth of 1930 eliminated many orchards on the Dekalb (Fig. 4), and the expected dry periods during the growing season may have serious consequences. The almost invariably close planting of the trees on the characteristically shallow profile has resulted in relatively small volumes of soil available for exploitation by the roots of each tree. Because of the frequently unfavorable moisture relationships, except in draws or other depressions, the trees commonly fail to attain the large size on the Dekalb (Fig. 5) that they do on the deeper limestone soils (Fig. 9). As orchardists constantly stress the necessity for obtaining a large tonnage of fruit per acre, the greater planting distances required by the Dekalb are seldom acceptable to them, so that close planting is still the rule.

While not at all numerous, there are still some ordinarily profitable apple orchards on the Dekalb; these are almost exclusively in the hands of owners or operators on the deeper areas who either have learned how best to manage orchards on that soil or have profited fortuitously from the management

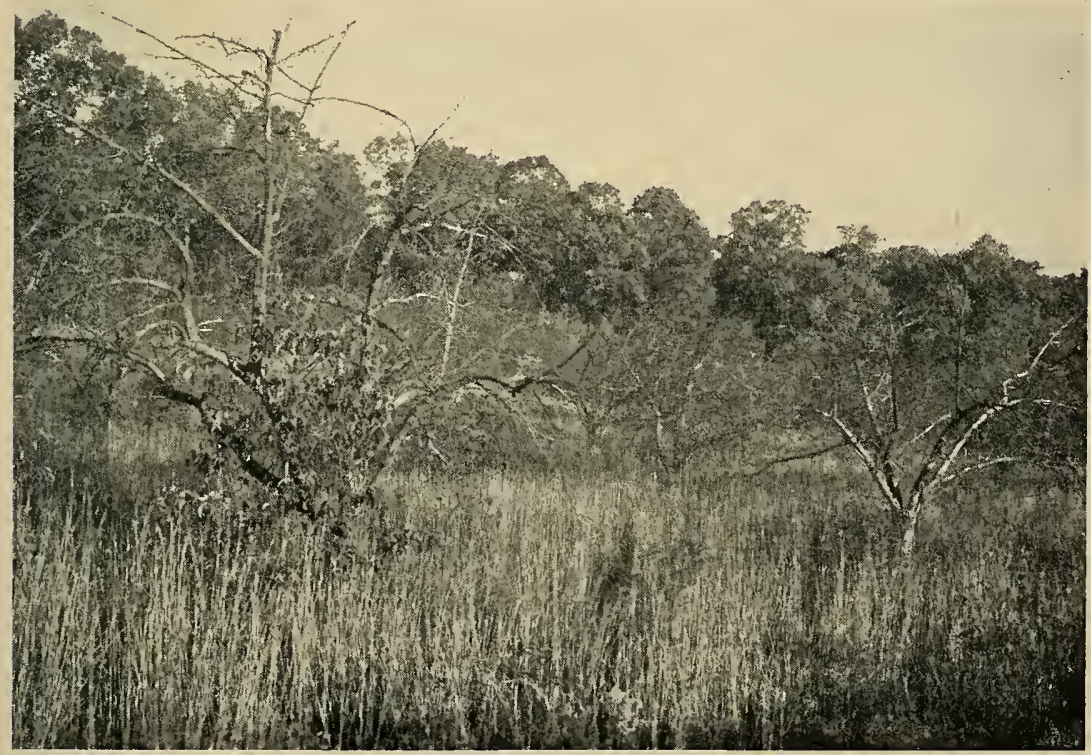

Fig. 4-An abandoned apple orchard on the Dekalb in midsummer. The drouth of 1930 ruined these trees 


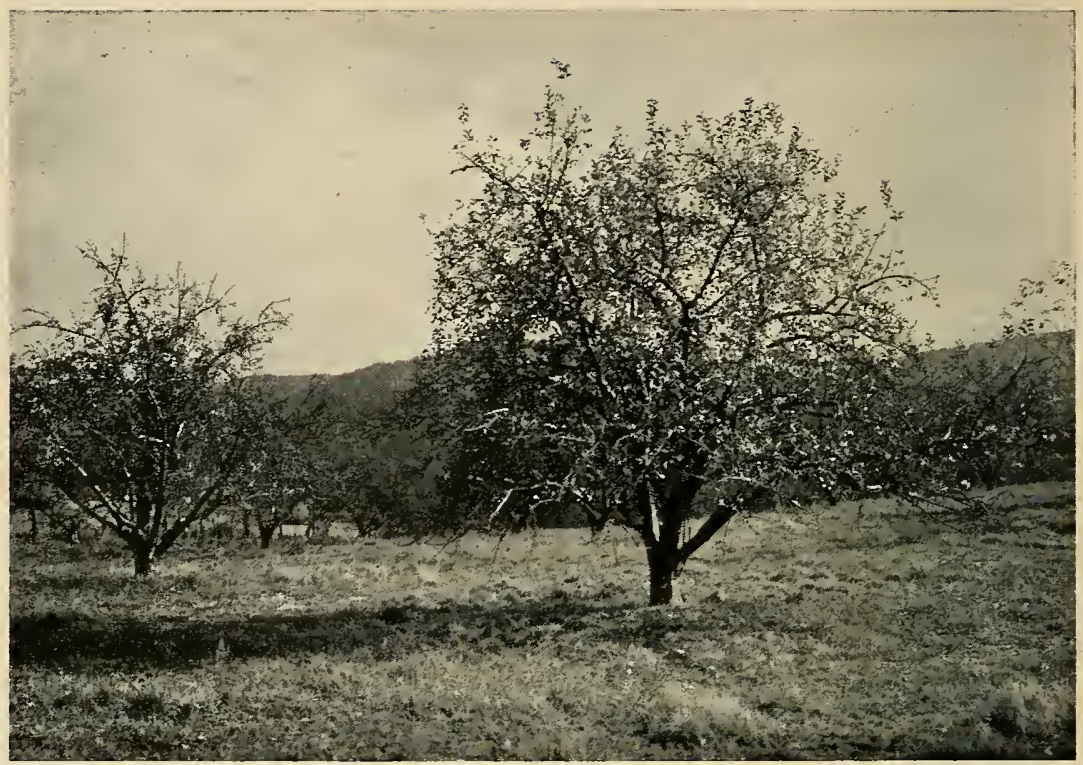

Fig. 5-A semi-abandoned orchard on the Dekalb. The trees which average about 12 feet high have never recovered

fully from the drouth of 1930

scheme followed. A low overhead and low costs of production may contribute to the attainment of a net profit in good seasons in spite of yields which average much lower than those of trees on the limestone soils. The comparatively low cost of control of the codling moth is also a factor frequently favoring orchards on the Dekalb; this, however, is not primarily a soil factor.

On the average, peaches have succeeded on the Dekalb much better than have apples, although the lack of size of the fruit is a serious handicap in dry growing seasons, especially when this occurs during the period of the final swell. The. more nearly frost-free sites more often found on the Dekalb have meant at times at least a partial crop of peaches in years of relatively higher prices, when many of the orchards on the more productive limestone soils have had crop failures due to frosts. This tendency to more regular peach production on the Dekalb than on the limestone soils is well known to orchardists of the Eastern Panhandle, some of whom possess orchards on both types and who have good comparisons in consequence of the relative consistency of performance of the trees.

The degree of red color on fruit grown on the Dekalb is likely to average greater than that produced on the limestone soils. 


\section{The Lebew Series}

The Lehew series, derived from the weathering of Indianred non-calcareous shales, comprises much of the distinctive red soils of the Eastern Panhandle. While they are not so extensive when compared with most of the other orchard soils in West Virginia, they are important in regard to the relative proportion of certain areas used for fruit growing. The Lehew is not found in West Virginia east of North Mountain. This soil appears often as narrow bands in conjunction with the Dekalb soils; in Hampshire County several considerably wider belts are to be found. As with the Dekalb, the topography varies from rounded hilltops and gentler slopes of rolling-tohilly valley areas to steeply sloping hills and mountain sides. Surface and internal drainage ranges from adequate to excessive, and erosion of unprotected surfaces is usually severe, especially on the steeper and unprotected slopes. The principal types of the Lehew are the fine sandy loam, the gravelly fine sandy loam, and the gravelly loam.

\section{FEET}

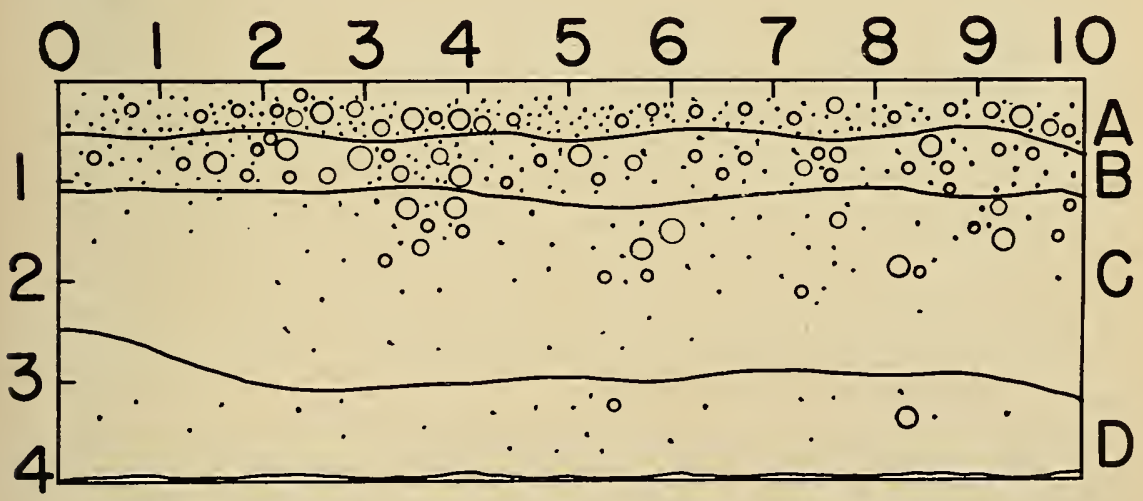

Chart 5-Root distribution on the Lehew fine sandy loam

A, dark brown fine sandy loam, loose, mellow; B, light brown to yellowish brown, fine sandy to silt loam, mellow, firm but not compact; C, dark reddish brown coarse sandy loam with sandstone fragments of varying size, extremely cemented and compact; D, dark reddish brown sandstone, partially decomposed, almost solid in places, very hard, roots penetrate only where crevices are located.

Chart 5 shows a typical root distribution of an apple tree on the Lehew fine sandy loam. The shallow depth is characteristic of the Lehew series. Several other root-distribution maps for this series, not presented here, show a similar shallow profile.

Mature apple trees on the Lehew series usually average small for their age (Fig. 6), and the necessity of heading back 
the tops to keep down the tree height is seldom a problem with these soils. Peach trees also average much smaller than on deeper soils. The typical bearing apple tree on the Lehew series appears characteristically semi-standard when compared with trees on the deeper limestone soils. As with the Dekalb,

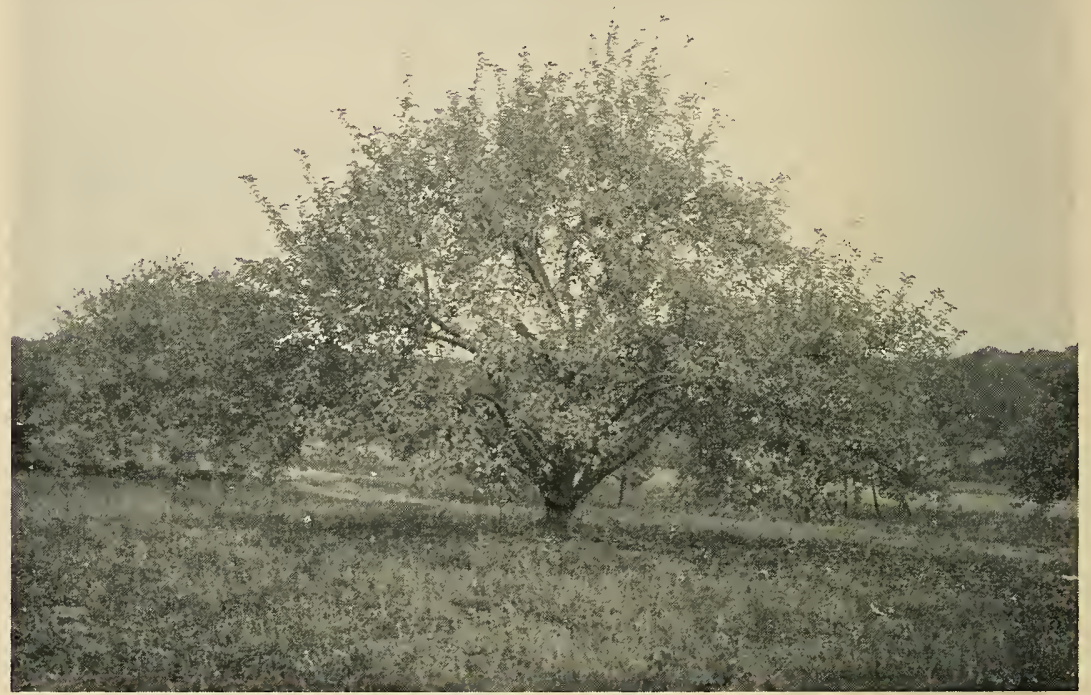

Fig. 6-An apple orchard on the Lehew. The trees, which averaged about 12 feet high, were injured in the drouth of 1930 . The shape of this York Imperial apple tree is typical for this soil series

the shallow soil of the Lehew, its abuse by improper cultural methods, and the close planting practiced have resulted in the availability of but a small soil volume for each tree. Other things being equal, growers prefer the Lehew to the Dekalb. The run-off and the consequent erosion on the Lehew are usually excessive, especially in peach orchards, because of the slope and the common mistreatment of the soil. The drouth of 1930 was felt very keenly by fruit trees on the Lehew. In seasons of a normal amount and distribution of rainfall, the color and finish of the fruit averages superior to that produced on the limestone soils.

Peaches, when set on the Lehew, bear with greater regularity than on the limestone soils because of the superior sites. It is due to this feature that commercial peach growing in West Virginia tends to concentrate on the Lehew and on the adjoining Dekalb soils. At the same time, apple growing is becoming of considerably less importance in the same areas. 


\section{SOILS DERIVED FROM LIMESTONE}

\section{The Elliber Series}

In acreage the Elliber series is one of the minor fruit soils of the Eastern Panhandle. It is, however, much more important than the relatively limited area would seem to indicate. This is because the Elliber ranks high in the proportion of the series used for orcharding.

The Elliber is found along the crests and shoulders of several of the hogback type of mountains characteristic of the Appalachians and on a few rounded knobs at 1200 to 2600 feet above sea level and usually from several hundred to more than 1000 feet above the floors of the adjacent valleys.

Exactly as with the shallower Dekalb, Lehew, and Berks series, the roots of apple trees penetrate the loose and incoherent mass of the Elliber soil (Fig. 7) until prevented mechanically from going deeper. In none of the excavations in the Elliber was solid rock encountered at the depth at which digging ceased, although rather hard and compact material was met at the bottoms of the holes. The continued sloughing off, caving in, and sliding of the sides of the trenches increased

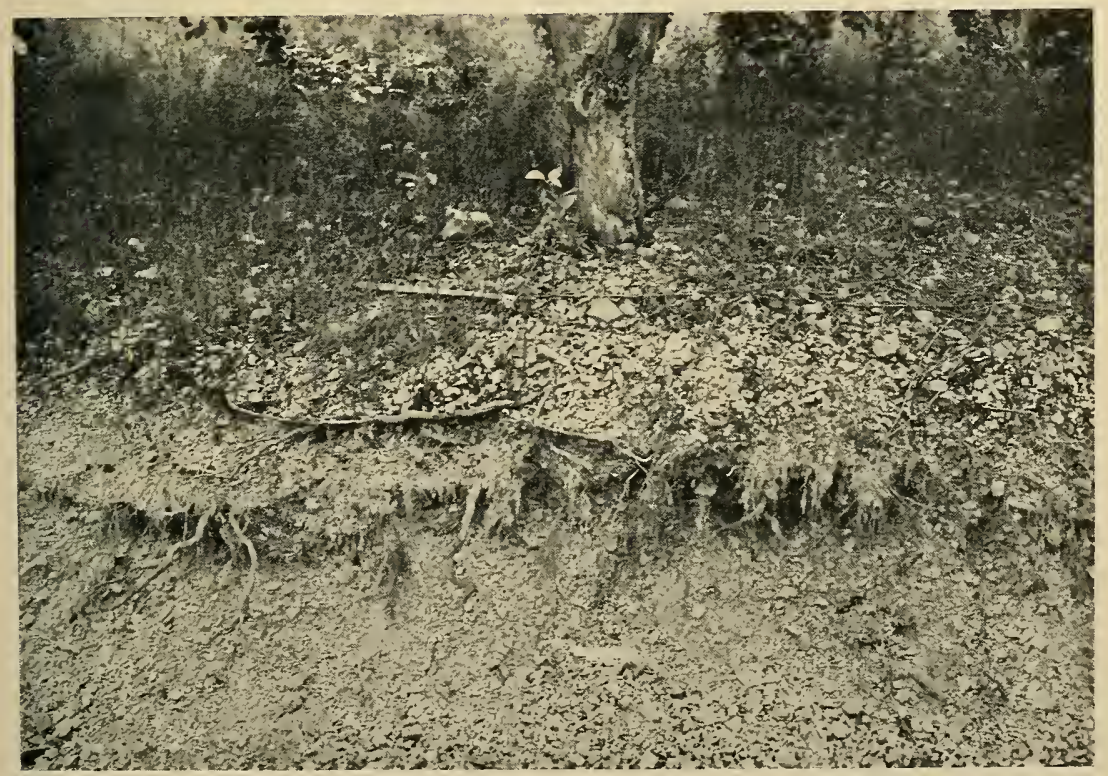

Fig. 7-A road-cut profile in an apple orchard on the Elliber series. Note the high content of chert. near the bottom of the picture 
the amount of work necessary in excavating and in mapping the root distribution with any considerable degree of accuracy.

Chart 6 shows the approximate vertical root distribution of an apple tree in the Elliber cherty loam. In all excavations made on this series, the roots penetrated at least 5 feet deep.

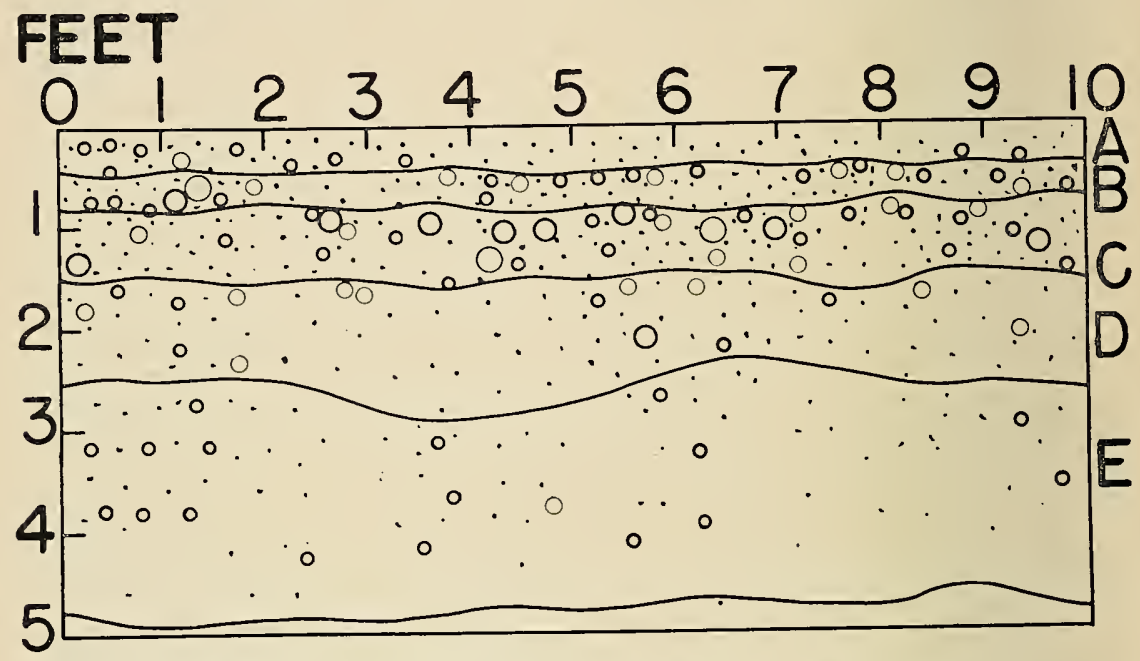

Chart 6-Root distribution on the Elliber cherty loam

A, black forest mold and litter, partially decayed, among interstices of chert of walnut size; $B$, light ashey grey cherty sandy loam, extremely cherty; C, yellowbrown cherty loam, chert of walnut size; D, chert with some olive-brown soil, particles mixed, very loose and incoherent; $\mathrm{E}$, olive-brown silt loam containing granitecolored sandstone fragments 6 inches to one foot in diameter, more soil than in layer D.

No compaction of the soil was observed in this trench; it was very loose and incoherent through the entire profile.

The advantages of the Elliber as a fruit-growing soil are several: it has been comparatively low-priced because of its sharply limited value for other kinds of agriculture. It is practically erosion-proof, almost regardless of how it is treated. In some instances it has been observed that furrows were plowed directly down steep slopes and still no erosion occurred because of the open layer of chert. The only soil cultural operations necessary for fruit growing are an occasional mowing of weeds and the application of nitrogen.

Among the chief disadvantages of the Elliber soils are the typically steep slopes and the usually high elevations above the surrounding country that must be climbed in order to reach orchards situated on this soil. These usually require the construction of numerous service roads more or less on the contour. However, this is easily done with a light road scraper; once made, these roads do not wash out as readily as might be expected. 


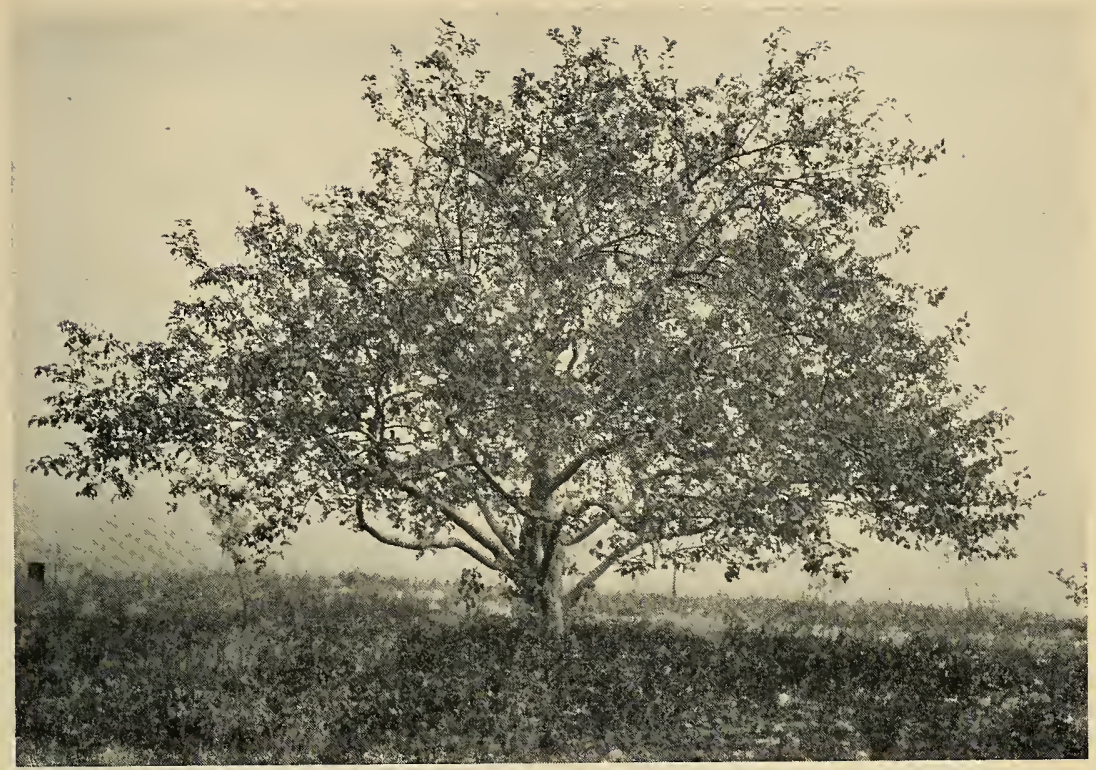

Fig. 8-A mature York Imperial apple tree on the Elliber. This individual, in common with most of the trees on this series, has been subjected to much wind distortion

Winter travel on such steep slopes is dangerous or impossible during periods of appreciable snow. Certain of the exposures are severely windswept and bleak, resulting in malformed trees impossible of correction by the pruner (Fig. 8) and, in some seasons, in much bruised and dropped fruit. Winter injury to fruit trees comes closer to being a problem on the Elliber than on any of the other soils of the Eastern Panhandle which are used in fruit growing.

The Elliber soils are highly valued for apple and peach growing, and the ownership of orchards on this series is concentrated in a relatively few persons who usually have continued to develop their plantings.

\section{The Frankstown Series}

The Frankstown soils are commonly found in close association with the other major limestone soil series, the Hagerstown and the Frederick. While the Frankstown series ranks second of the three in total area it is probably the first in respect to the proportion of its available area occupied by orchards.

The famous Apple Pie Ridge, which in reality consists of a variably wide belt of several low ridges averaging approxi- 
mately a mile wide, extends from a considerable distance south of the Virginia line to Maryland at the Potomac River. Much of its soil originally was classified largely as Frankstown, although the Frederick and the Hagerstown series are also prominent. It was on Apple Pie Ridge, although only in part on Frankstown soil, that commercial orcharding in the Eastern Panhandle began during the Civil War.

A second and much more extensive belt from $2 \frac{1}{2}$ to $31 / 2$ miles wide, consisting chiefly of the Frankstown, extends west of the Shenandoah River in Jefferson County from Virginia to Maryland. It was on this latter area of the Frankstown that the first orchard of record in what is now West Virginia was planted in 1774 by a certain Wm. Bartlett on land leased from George Washington of Mount Vernon.*

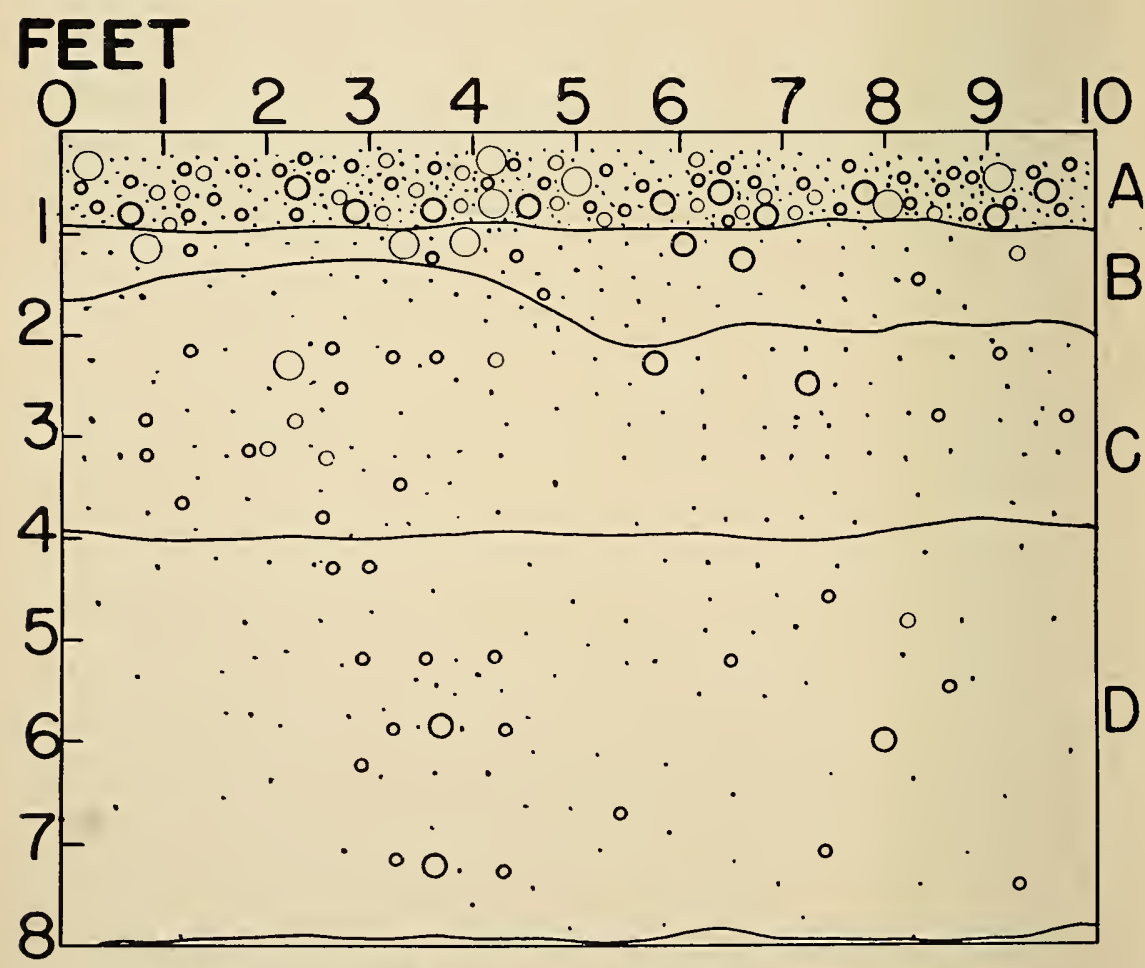

Chart 7-Root distribution on the Frankstown silt loam

A, dark brown silt loam, firm but friable and with fragnients of yellow soapstone and with some small gravel scattered in the surface; $B$, yellowish brown " silt to silty clay loam, gravelly, with yellow soapstone fragments; C, Indian-red clay to silty clay; D, Indian red, orange, and yellow clay, less structure than in layer $C$.

A root $20 \mathrm{~mm}$ in diameter was directed straight down in the bottom of the excavation.

*Deed Book No. 3, page 1, Records of Berkeley County, West Virginia. 
Charts 7 and 8 show typical vertical distributions of appletree roots in the Frankstown silt loam, the most extensive type. The silt loam type grades imperceptibly into the gravelly silt loam, which contains up to about 40 percent gravel. The root distribution appears to be approximately the same for either soil type or for its intergrades.

In Chart 7 it will be noted that apple roots, some of considerable size, were still to be observed at $71 / 2$ feet, at which depth one root $20 \mathrm{~mm}$ in diameter was directed straight downward in the bottom of the excavation.

In Chart 8, while soapstone was met at $31 / 3$ feet in one end of the trench, the seams in the soft material were filled with a silt to a silty clay material in which tree roots had ramified.

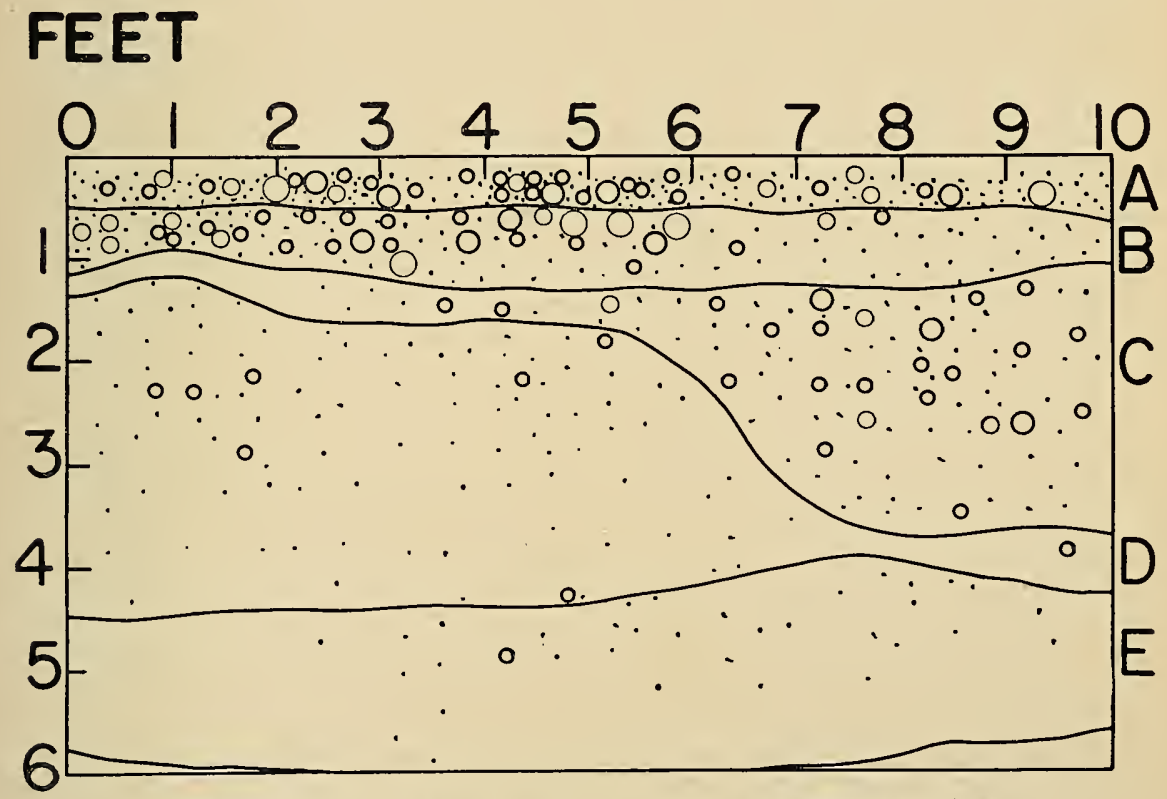

Chart 8-Root distribution on the Frankstown silt loam

A, brown silt loam, smooth and velvety with small fragments of yellowish soapstone, and chert on surface; B, yellowish brown silt loam, firm, scattered small fragments of yellowish soapstone and chert; C, yellow-brown silty clay with irregular seams of soapstone, slightly compact; D, gray, yellow, and rusty brown silty clay, compact; E, soapstone with seams of yellow and orange silt to silty clay, firm but not compact.

With other charts of the Frankstown, the roots continued until rock was reached; in some local areas of the shallow phase of the silt loam, which is of limited extent, this was a matter of only 3 to 4 feet, although on the normal Frankstown 
it averaged in general approximately 6 feet. A relatively large volume of soil is usually accessible to the roots of apple trees set on the average soils of the Frankstown series. Occasional rock outcrops appear on the Frankstown, especially in areas of the shallow phase with its greater degree of geological erosion.

The Frankstown is one of the superior orchard soils of the Shenandoah Valley. Apple trees in this silt loam and on much of the gravelly silt loam may attain large size (Fig. 9); on the less important shallow areas the size runs smaller.

\section{The Hagerstown Series}

The Hagerstown is by far the most extensive soil series in the Shenandoah Valley of West Virginia. However, not as large a proportion is in orchards as in the case of the Frankstown series, for the Hagerstown is especially prized for general farming. Also, reasonably frost-free sites are somewhat more difficult to obtain on the Hagerstown. The Hagerstown is typically gently undulating to rolling; a few smaller and less important areas of the stony clay loam are found on several of the ridges of the Appalachian Mountains. The Hagerstown soils are inherently fertile, as the bases have not been leached out very thoroughly. Limestone outcrops are a common feature of the Hagerstown topography, as also, to a lesser extent, are sinkholes in certain areas.

The Hagerstown series are typically heavy soils varying in surface texture from a silt loam to a clay, partly as the degree of erosion increases and the subsoil becomes more prominent in the surface, and partly according to the texture of the impurities in the massive limestone from which the parent material was derived. The typically excellent structure of the Hagerstown series has made possible the development of a large number of good commercial orchards on soil of such fine texture. The natural internal drainage is normally good even in slight depressions where surface drainage is impossible.

As Charts 9 and 10 show, the Hagerstown is typically a soil on which deep rooting of the trees occurs. The junior author has observed apple-tree roots at a depth of 21 feet in the Hagerstown soil of Pennsylvania.

Little comment on the charts is required. With such deep rooting, even with trees set too close for the most efficient development of their tops, the soil volume available for the roots of each tree on the phases of normal depth is relatively very large. The high content of available water possible in these soils explains why fruit trees on the normal types of the Hagers- 
town have been able to endure severe drouths, such as that of 1930 , as well as or better than those on any other soil series in the Eastern Panhandle.

As with the other orchard soils of that area, the tree roots penetrate downwards until they are stopped mechanically. On some of the areas of the shallow phase and frequently near outcrops in a field of even the normal Hagerstown, the soil depth may be severely restricted. Trees set in such areas appear to be handicapped roughly in proportion to the reduction in the vol-

FEET

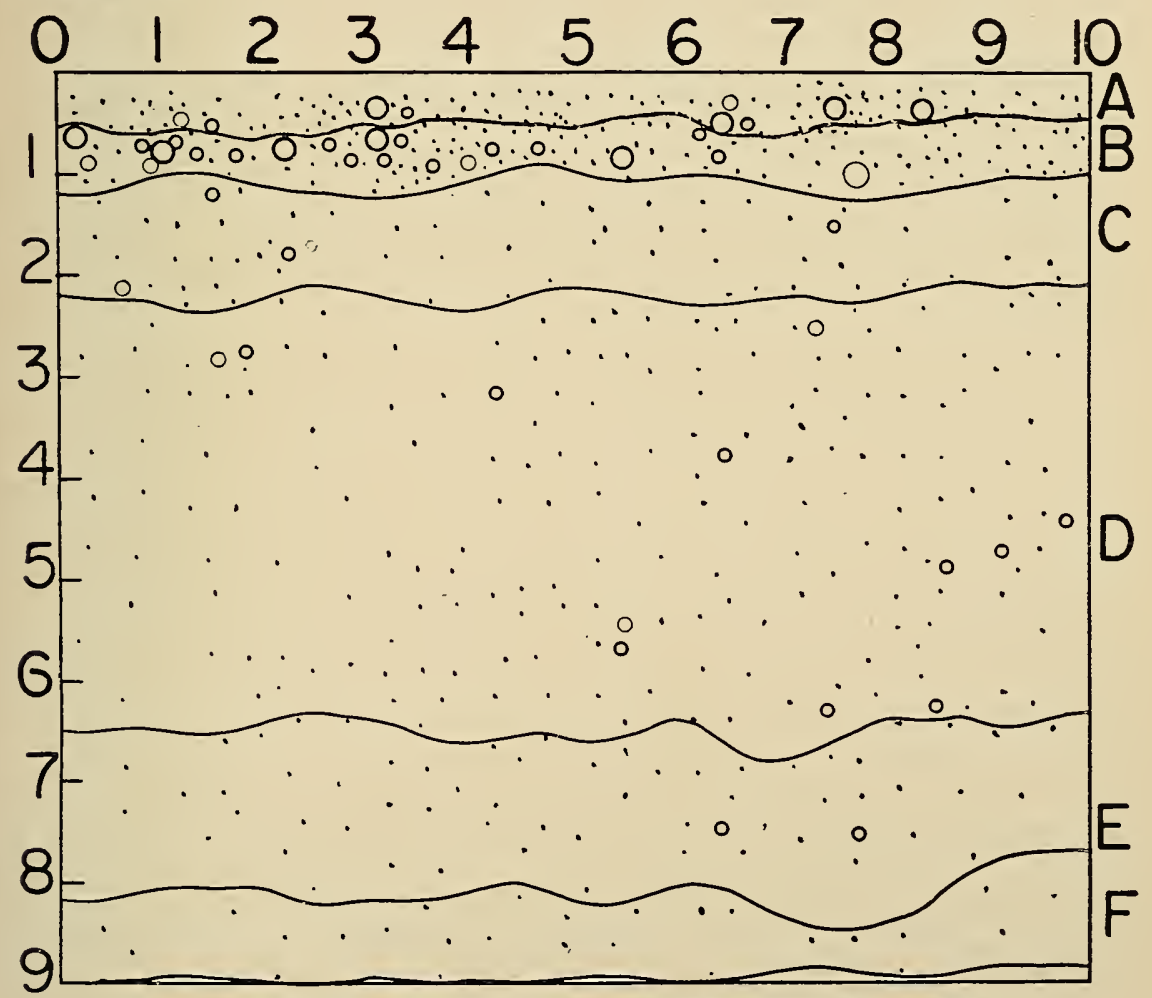

Chart 9-Root distribution on the Hagerstown silt loam

A, light brown silt loam, smooth and velvety, firm but not compact; B, light greyish yellow to yellowish brown, same as layer A without organic matter; C, reddish brown clay streaked with gray, very hard and compact-appearing, and cemented where iron concretions are most numerous; D, reddish brown to Indian-red clay, very stiff and hard, with slightly columnar structure, roots in this layer tend to follow the vertical cleavage planes; E, reddish brown clay with irregular patches of greenish yellow clay of massive structure; F, reddish brown silty clay, massive structure, more friable than $\mathrm{D}$ and $\mathrm{E}$.

Roots extended an undetermined distance below 9 feet in this profile. 
ume of the soil available for rooting. Individual trees planted near outcrops may attain very large size, or they may exhibit any degree of dwarfing, depending on the particular circumstances. Most orchards in the Hagerstown have at least a few trees which for these reasons have never developed properly. Resets in such unfavorable spots usually perform very much like the original trees which they replaced.

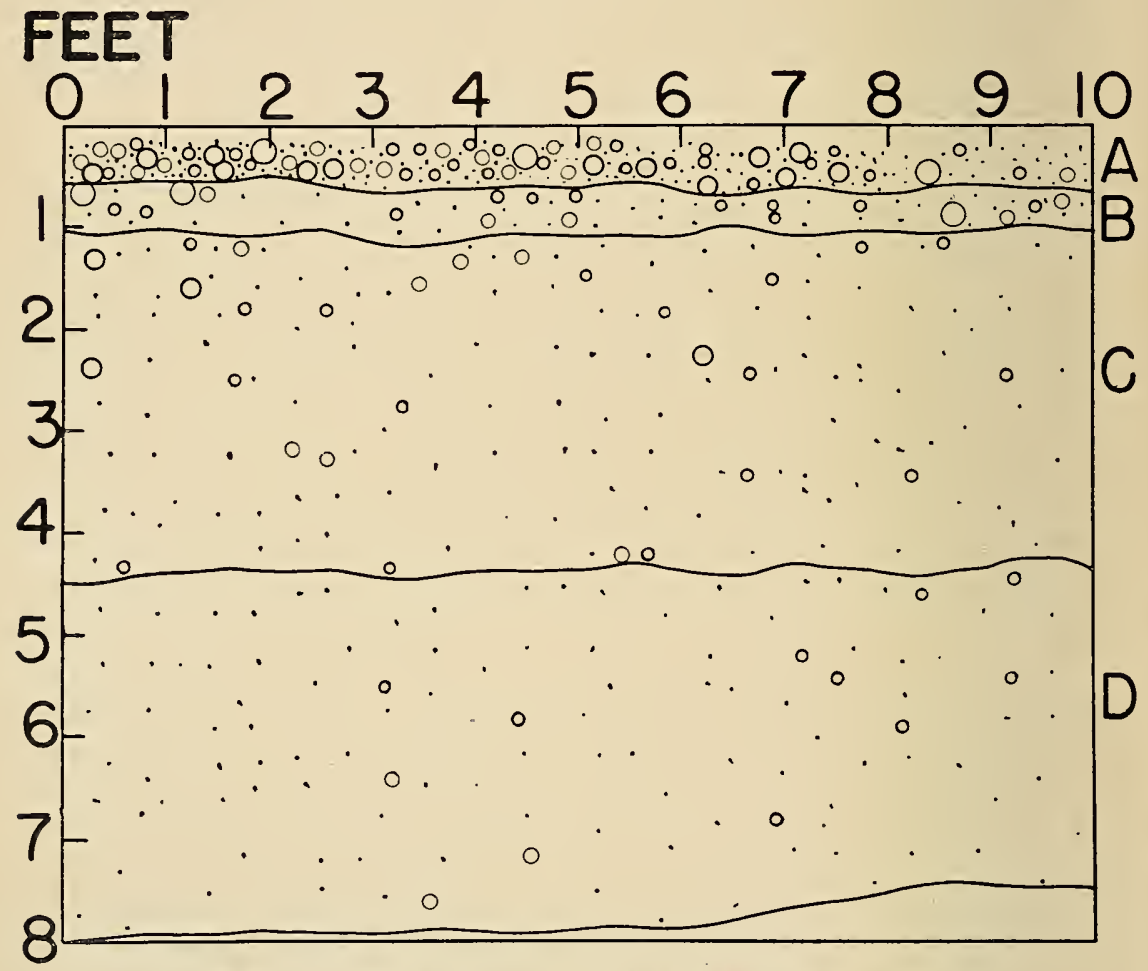

Chart 10 -Root distribution on the Hagerstown silt loam

A, light brown silt loam, friable but firm; B, pale yellow red silty clay loam, hard when dry; C, Indian-red clay, hard and compact, with vertical and horizontal cleavage planes; D, Indian-red silty clay to clay with streaks of greenish yellow sufficient to give a mottled appearance, firm, massive structure, not as hard and compact as layer $\mathrm{C}$; $\mathrm{E}$, light orange-red silt to silty clay, firm massive structure, not as hard as layer $D$.

Roots extended an undetermined distance below $7 \frac{1}{2}$ to 8 feet in this profle.

Barring accidents and diseases, apple trees set on the normally deep Hagerstown soils usually attain very large size (Fig. 9) for the varieties and ages. A planting distance of $40 \times 40$ feet is too close for most of the standard apple varieties worked on the ordinary seedling rootstocks. Few of the commercial orchards were set at more than 36 feet. 


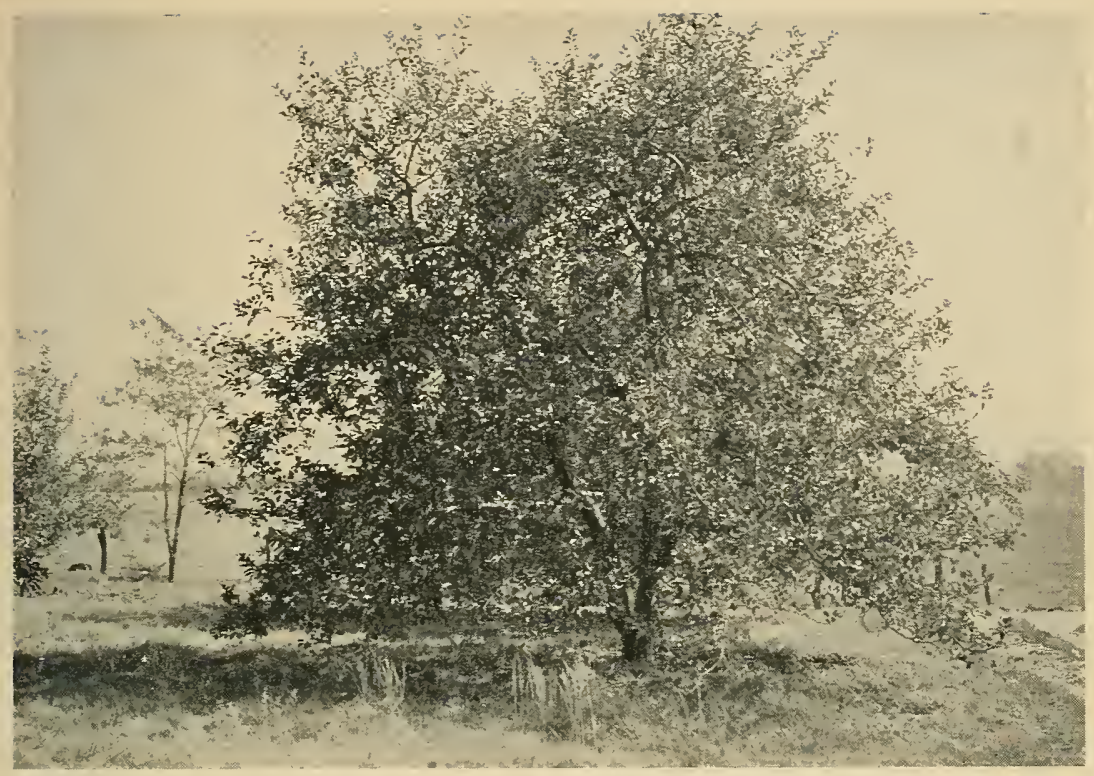

Fig. 9-A York Imperial apple tree on the Frankstown series. This individual, which is about 30 feet high, serves equally well as an example of trees on the Hagerstown and on the Frederick series, both of which are present within 100 yards of this point

Partly because of the nature of the soil, partly because of the close planting and attendant crowding, and in addition because of climatic and other environmental factors, apple fruits on mature trees on the Hagerstown tend to be lacking in red color even in many apparently normal seasons. In attempts to remedy this condition, some of the red sports of the standard varieties are being employed.

\section{The Frederick Series}

The Frederick completes the three major limestone orchard soils of the Eastern Panhandle. All of these may appear in narrow belts in close proximity, often repeatedly as one traverses the same orchard, even within a few tree rows of each other. Locally shale as well as limestone has contributed to the formation of this series.

The Frederick is more rolling than the Hagerstown, with which it is closely associated in West Virginia; it is well drained and varies considerably in depth. Bedrock is said to lie deeper with the Frederick than with the Hagerstown, according to Alexander et al. (1). The same authorities have observed that the Frederick is not so fertile naturally as the Hagerstown, as 
the former has been more thoroughly leached and is consequently poorer in bases.

No root-distribution charts are available for the Frederick. However, several chemical and physical determinations have been made with this series which may be compared with those of the Hagerstown and of the Frankstown. From soil samples, from studies of several road cuts, and from the reports previously referred to, it is evident that the subsoil of the Frederick is somewhat heavier and more compact than are those of the Frankstown and Hagerstown series. Although the subsoil of the Frederick is heavy and apparently tight, it breaks out rather easily and the roots of apple trees seem to have no difficulty in penetrating it under West Virginia conditions.

The chemical compositions of the Frederick and the Hagerstown soils are very similar; the heavier-textured parent material of the former and the yellow instead of the red color with the brown was the basis of separation of the 2 series. While it is stated (1) that "It seems likely that sometime in the recent past the [Frederick] soil has been waterlogged owing to a very poor internal drainage," there is no evidence at present of failure of internal drainage in the West Virginia orchards studied.

Limestone outcrops are prominent on the shallow phase of the Frederick. When all three limestone soils were closely associated on similar topography in the same orchard (Fig. 9), as occurred several times in the course of these studies, there was no apparent difference between the trees on each series. With all of these limestone soils discussed thus far, the size of the trees of a given variety seems to be chiefly a reflection of the original condition, including depth, modified favorably or otherwise by subsequent management.

\section{The Colbert Series}

The present importance of the Colbert as an orchard soil would not justify its inclusion in this bulletin if it were not for the fact that it is still considered occasionally for orchardsthis despite convincing evidence that no commercial orchard has ever been successful on the Colbert.

The Colbert silt loam, the only type mapped, occurs on areas varying from gently undulating to slopes of about five or six percent at the base of North Mountain and extending eastward to the gentle elevations of Apple Pie Ridge. The Colbert is generally at slightly lower elevations than the neighboring areas of Hagerstown, Frankstown, and Frederick soils. Like those three series it is of limestone origin. Yet the Colbert is 
quite unlike them, being entirely unsuited to orcharding. The usual difficulties encountered with this series are generally poor internal drainage plus a very high degree of erosibility, more so than that of any of the other upland soils of the Eastern Panhandle. The severe gullying which has occurred on areas of this series makes it a soil which must be protected carefully from erosion. This essential protection takes the form of costly engineering structures, or some permanent surface cover, or both. Some of this water comes from precipitation falling directly on this soil, while part of it represents run-off descending from the extensive slopes of North Mountain.

The Colbert has been used for orchards partly because it is so closely associated with the superior limestone soils (Fig. 9) that it is possible for plantings primarily on the latter to "overflow" unnoticed upon the Colbert. One not informed of the distinguishing characteristics of this series would not immediately suspect the undesirable sub-surface changes it apparently always possesses. The grey-mottled plastic yellow clay subsoil and the small iron concretions usually found through the profile distinguished the Colbert from the redder subsoils of the other limestone series, which are customarily lacking in concretions.

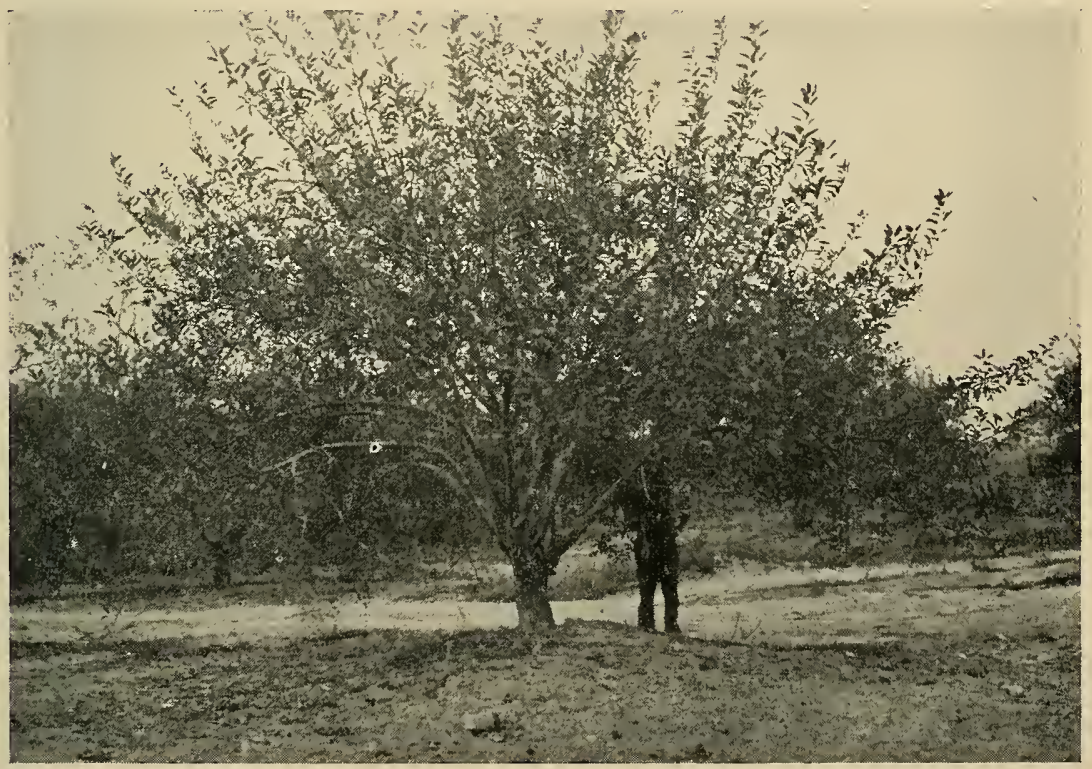

Fig. 10-An apple tree on the Colbert series. Note the mound on which the tree is standing. Erosion is always severe on unprotected soil surfaces of the Colbert 


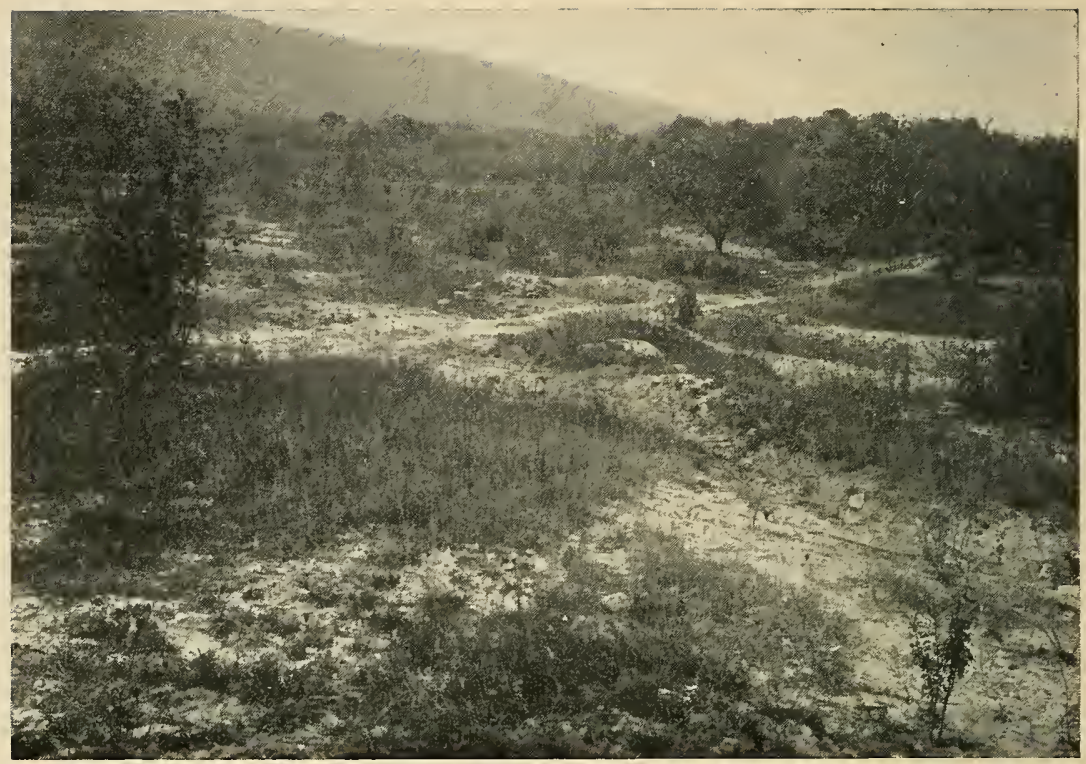

Fig. 11-The apple trees on this area of the Colbert were removed because of severe erosion. The trees on the point to the right are on the Frederick, which is not in such bad condition

No root distribution or other studies were made in the one commercial orchard which was located in part on the Colbert, as most of the mature apple and peach trees originally standing on this series were either pulled because of a condition of hopelessly severe gullying (Fig. 11), or else were semi-dwarfs standing on "islands" or mounds from one to three feet higher than the surrounding soil surface (Fig. 10). 


\section{PHYSICAL AND CHEMICAL CHARACTERISTICS}

The determinations of the physical and chemical characteristics of the surface and subsoil samples from representative orchards of the Eastern Panhandle of West Virginia are presented in Tables 1 and 2. The soils are grouped on the basis of origin into two divisions, the one including those derived from the sandstones and shales, the Lehew, Dekalb, and Berks series, and the other comprising those of limestone origin, the Hagerstown, Frankstown, and Frederick series. Separations have also been made on the basis of cultural treatments into sod and cultivated sites. The age and the type of the sod varied considerably, but in general each represented a wellsodded area of bluegrass or a mixture of bluegrass and other native grasses undisturbed for many years.

While the term cultivation represents a system of orchardsoil management that has included several diskings a year at some earlier period in the history of the orchards, there are seldom available any reliable records of the duration and intensity of cultivation; the operators rely almost entirely on memory. More recently, however, all of these orchards have either been seeded to some type of grass or legume; or they have been allowed to grow up to volunteer native vegetation. Although at present few bearing apple orchards in the Eastern Panhandle are cultivated, intensive tillage is still all too common in peach orchards in West Virginia. But little thought is given, in most cases, to growing adequate cover crops, to applying mulches, or to other soil conservation practices as aids in conserving soil and water, both of which are of vital importance.

Preliminary analysis of the data showed that, due to soil type, there were highly significant differences in nearly all factors in both the surface soils and in the subsoils. The exceptions were organic-matter content and the percentage of aggregates greater than $0.25 \mathrm{~mm}$ in the subsoil. A comparison of the data in Tables 1 and 2 shows that the limestone soils differ from the soils derived from sandstone and shale in certain of the physical and chemical characteristics. The analyses in Tables 3 and 4 show highly significant differences in all properties studied both in the surface and in the subsoils with the exception of the organic-matter content of the surface soils. The soils derived from limestone are higher in moisture equivalent, organic-matter content, aggregates greater than $0.25 \mathrm{~mm}$, particles less than $0.05 \mathrm{~mm}$, and lower in dispersion ratio and in particles greater than $0.25 \mathrm{~mm}$ than were the soils derived from sandstone and shale with the single exception already noted.

It has been shown by several investigators $(2,3,6,17,21$, and 22, ) that the cultural treatment infiuences very materially 
certain of the physical and chemical properties of soils, such as organic-matter content, aggregation, dispersion ratio, and volume weight. The data presented herein show that the surface samples from sodded sites possess higher moisture equivalent, organic-matter content, and aggregates greater than 0.25 $\mathrm{mm}$, than do the cultivated sites; in contrast, there are no significant differences in the dispersion ratio, in particles greater than $0.25 \mathrm{~mm}$, or in the particles less than $0.05 \mathrm{~mm}$. In the subsoil the organic-matter content is the only characteristic which is altered significantly by the cultural treatments.

\section{Moisture Equivalent}

The moisture equivalent is dependent to a very large extent upon the size distribution of the soil particles, although it is influenced by other factors among which are soil structure, organic-matter content, and type and amount of colloidal material present. The moisture equivalent of the Lehew soils is lower than that of the other soils because of coarser texture. However, if the Lehew soils are omitted from the calculations, then the moisture equivalents of the other soils do not differ significantly.

On the average, the soils derived from limestone contain a higher percentage of the fraction less than $0.05 \mathrm{~mm}$ and a smaller percentage of the fraction greater than $0.25 \mathrm{~mm}$ than do the soils derived from sandstone and shale. The average organic-matter content is also higher in the limestone soils. Therefore it is not surprising to find that the moisture equivalent of the limestone soils is significantly higher than that of the sandstone and shale soils. Apparently the higher moisture equivalent of the sodded sites in the surface samples is due largely to their higher organic-matter content, although there may be small differences due to soil structure.

\section{Mechanical Analysis}

A complete detailed mechanical analysis was not made; instead, separations included the fractions greater than 0.25 $\mathrm{mm}$ and less than $0.05 \mathrm{~mm}$. The sandstone and shale soils contain a considerable amount of undecomposed shale particles which appeared in the fraction greater than $0.25 \mathrm{~mm}$ in the mechanical analysis. The limestone soils, because of the nature of the parent material, contain a very limited amount of the coarser fraction and a large amount of the finer fraction than the sandstone and shale soils. Reference should be made to Tables 1 and 2 for the detailed data. It should be recognized, of course, that certain limestone soils may contain undecomposed shale particles, the amount depending upon the degree of weathering and upon the composition of the parent material. 


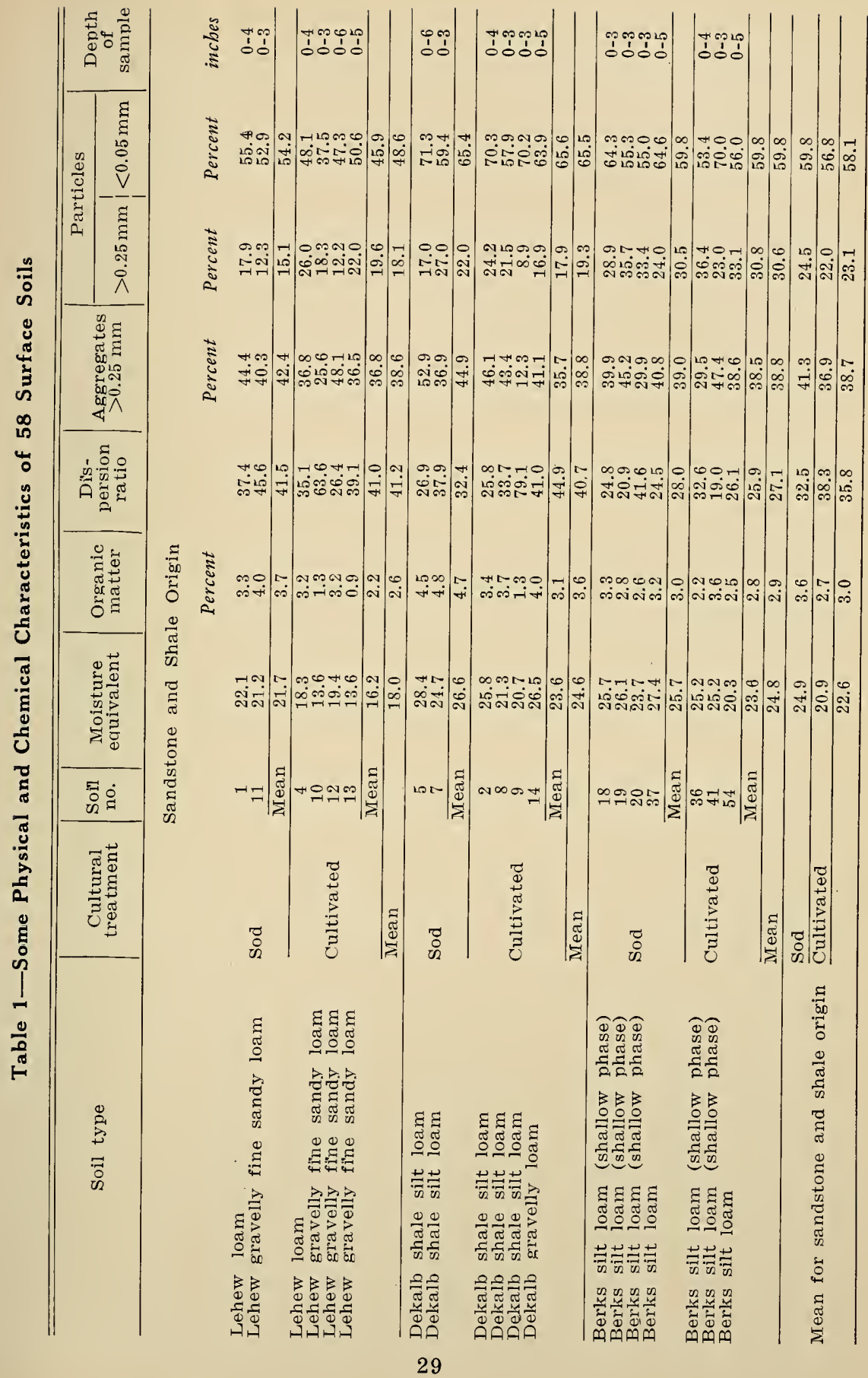




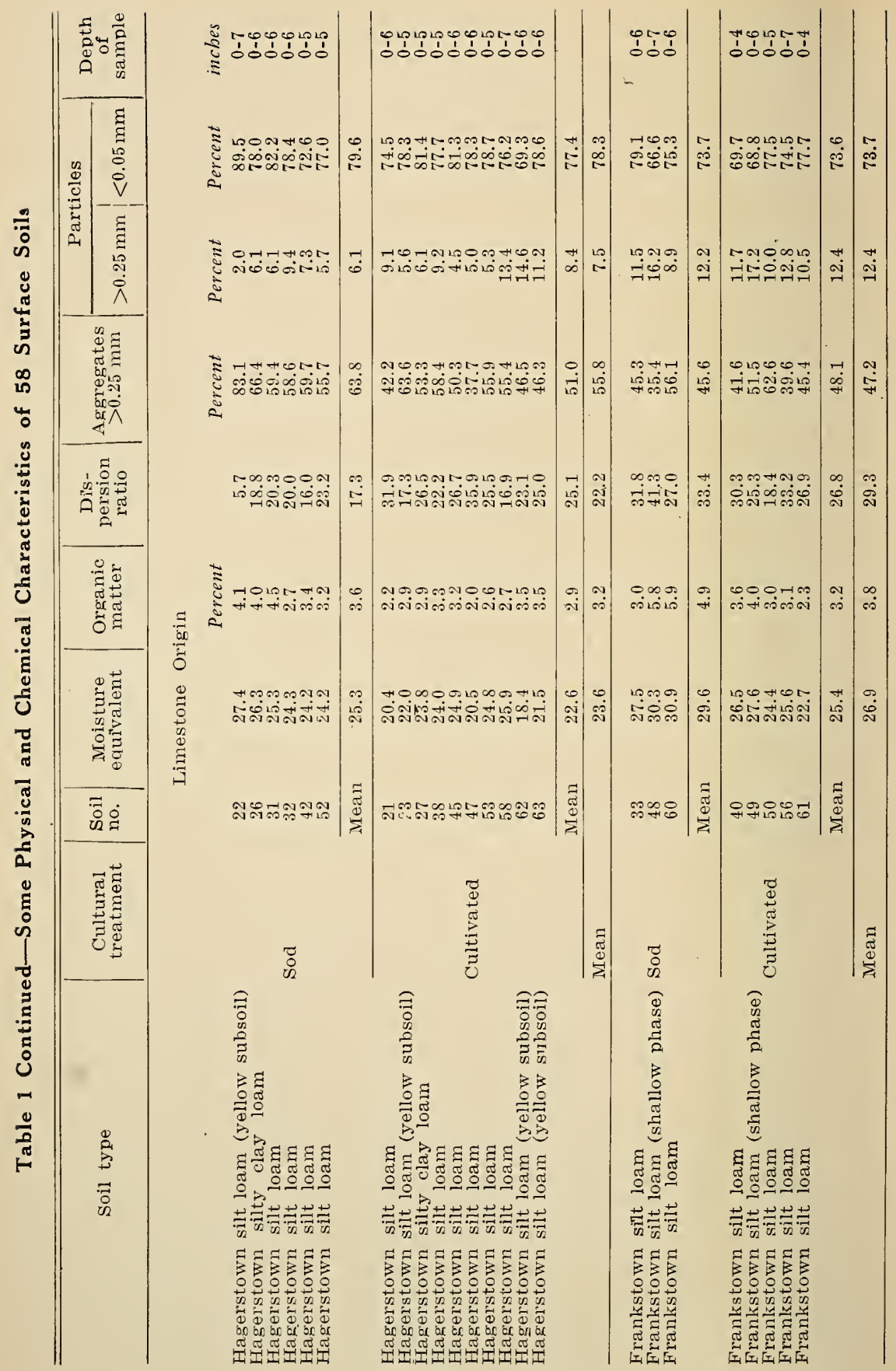



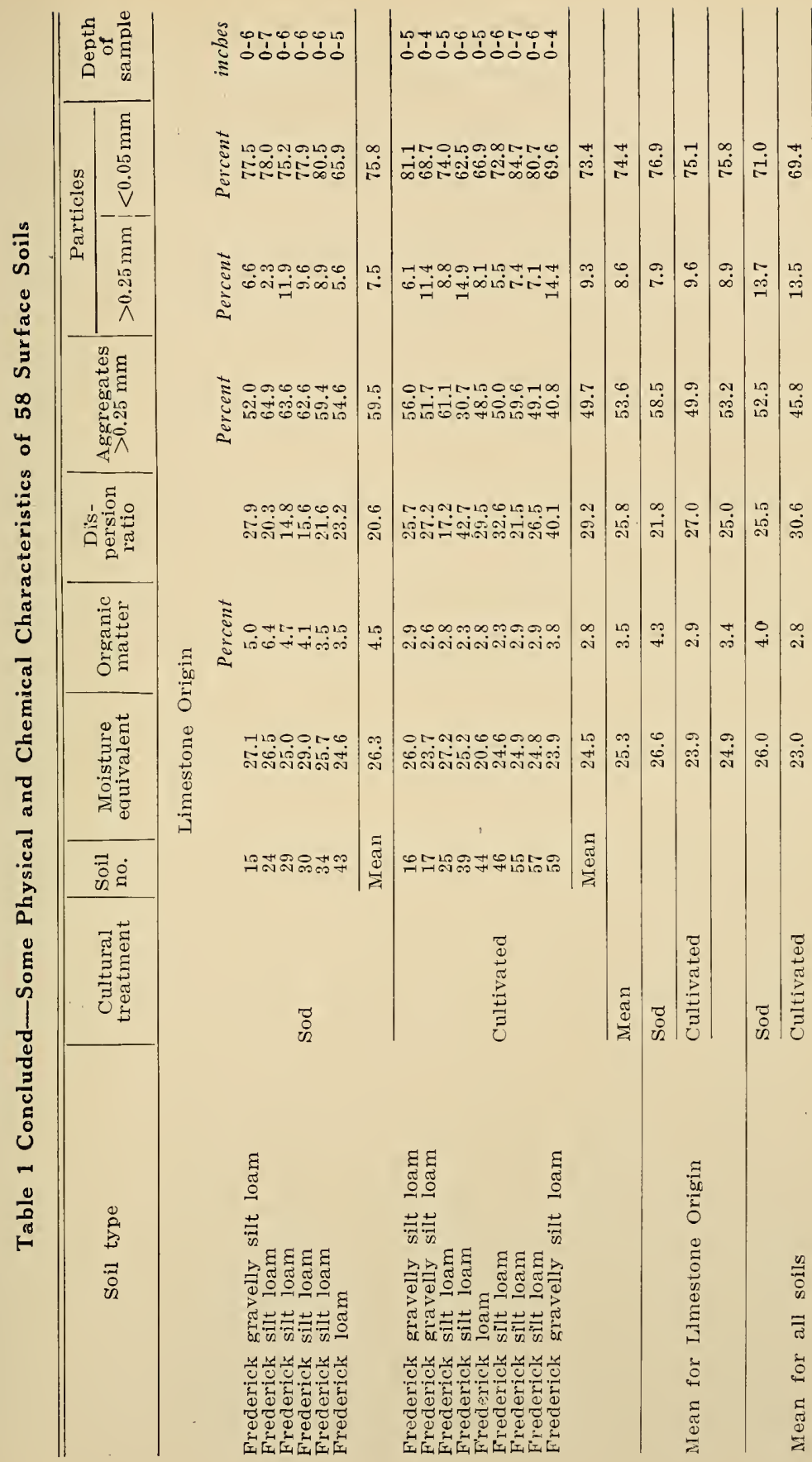

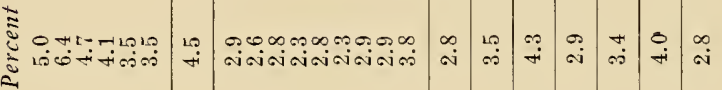

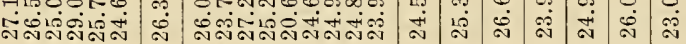

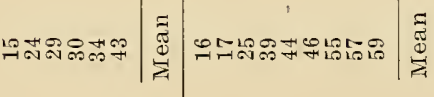

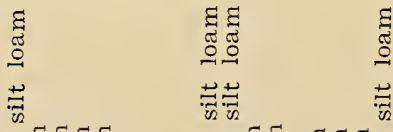

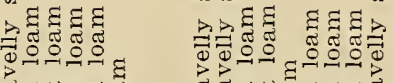

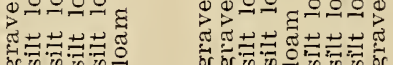

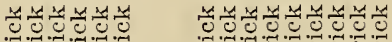
ज्ञ

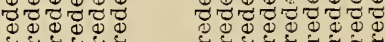
(1) $\Phi_{0=1}^{\infty} \Phi_{\infty=1}^{2}$

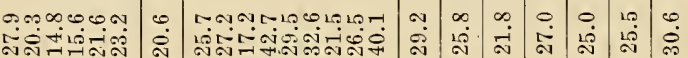
סृ
ஸे

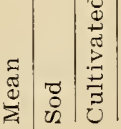




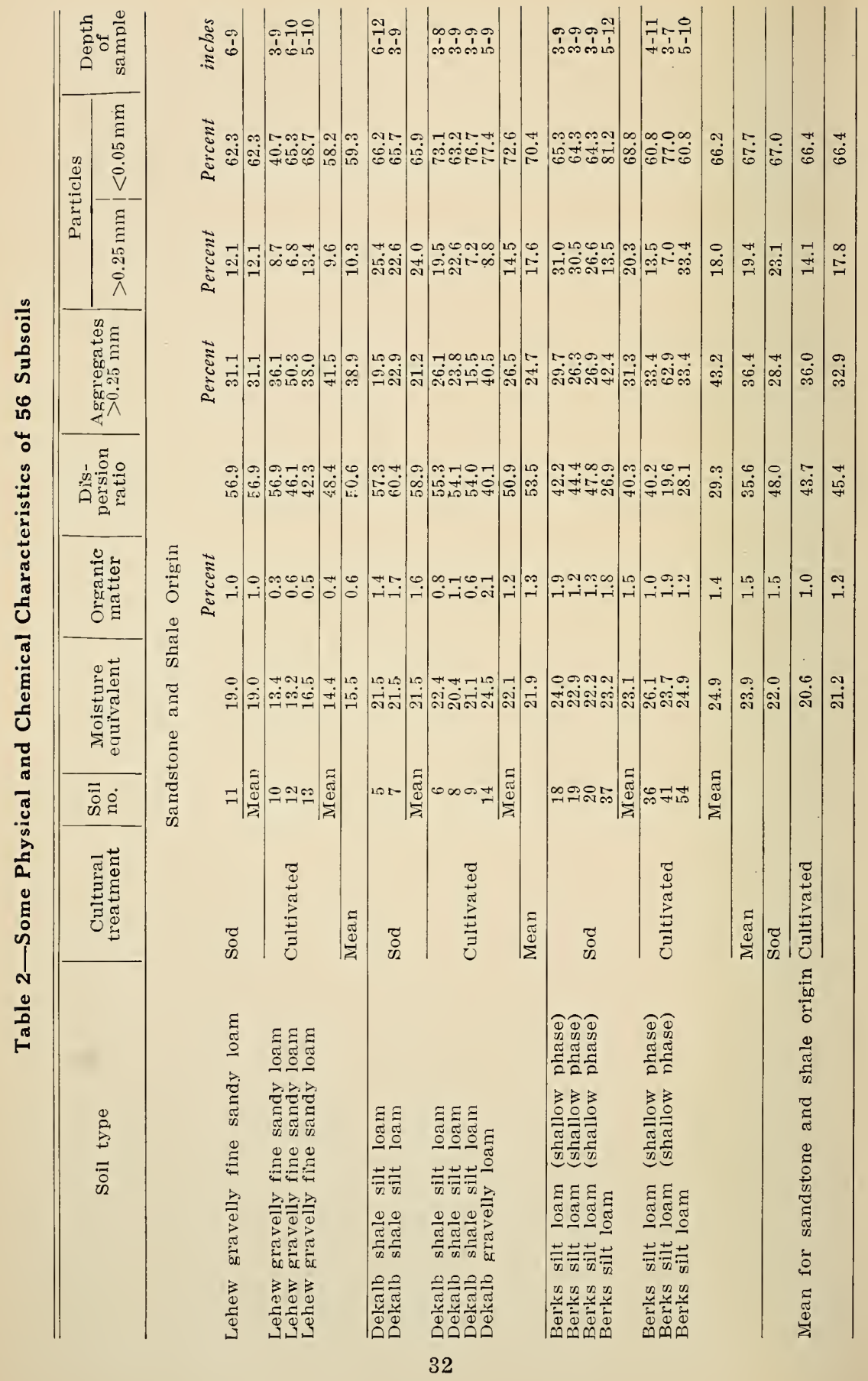




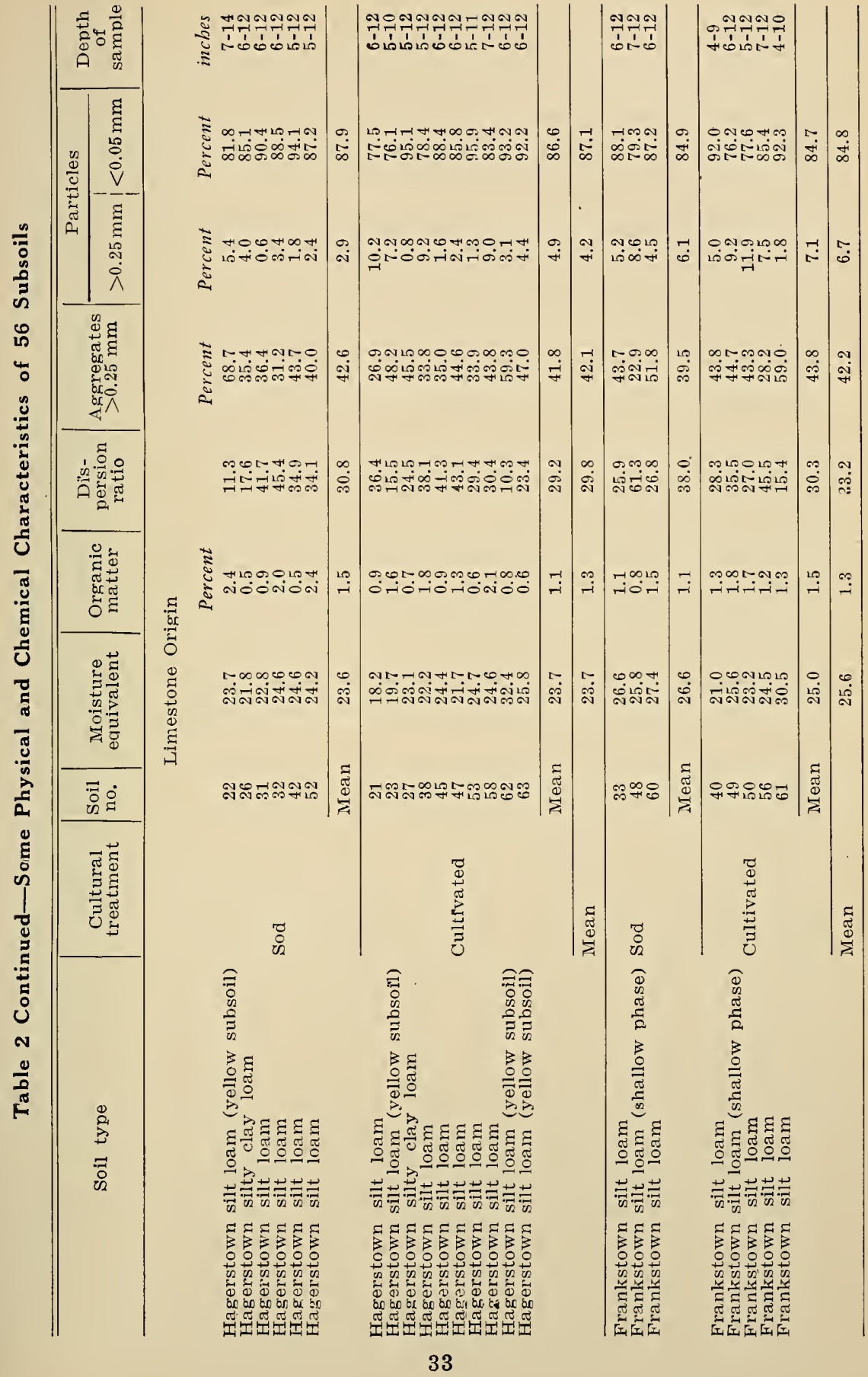




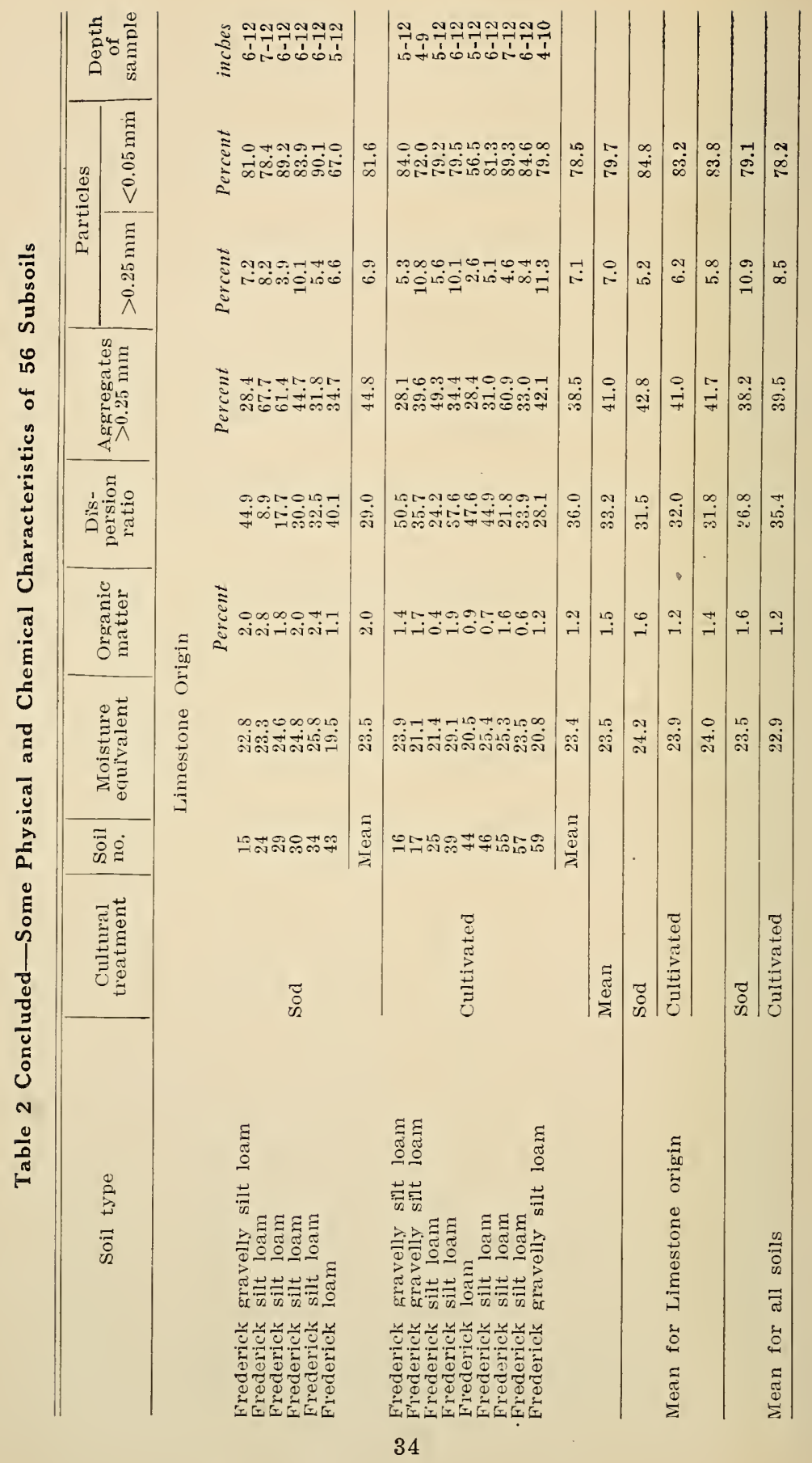




\section{Organic Matter}

The organic-matter content of soils developed under uniform cover and climatic conditions is influenced to a large extent by the previous cultural treatment. Cultivation depletes organic matter, while sod maintains or increases it. The development and maintenance of desirable structural conditions in soils is dependent upon the presence of an adequate supply of organic and inorganic material to bind the soil particles into aggregates. When depleted of their organic matter, soils of this region that are texturally silt loams generally have a very poor structure, are easily dispersed, and are subject to severe erosion. Clean tillage temporarily increases biological activity, and the tendency is for the amount of the organic matter to decrease unless unusually good soil-management practices are adopted, including the incorporation of very large amounts of cover crops or of plant residues.

In the Cumberland-Shenandoah Region most of the grass roots are located in the surface soil; consequently the organicmatter content in the surface soil is much higher than in the subsoil. Therefore the structural conditions of the subsoil are influenced to a larger extent by the inorganic colloidal fraction. In many silt loam soils the amount of inorganic colloidal material is limited and the degree of aggregation will be influenced largely by the organic-matter content. Clay soils will be influenced less by changes in organic matter than will silt loams, while sandy soils will be affected the least. With all of the soils in the study, the texture is such that organic matter plays a major role in the development of a structural condition conducive to the maximum absorption and hence to the minimum losses of water.

The relation of organic matter to the state of aggregation in the surface and in the subsoil is presented in Charts 11 and 12. An increase in organic matter is accompanied by an increase in aggregation; this is an agreement with the observations of other investigators.

The differences in organic-matter content of the limestone and of the sandstone and shale soils are not significant even though the former group has greater potential fertility. This emphasizes the fact that the cultural treatment past and present may have a greater effect than does soil type upon certain soil properties. 


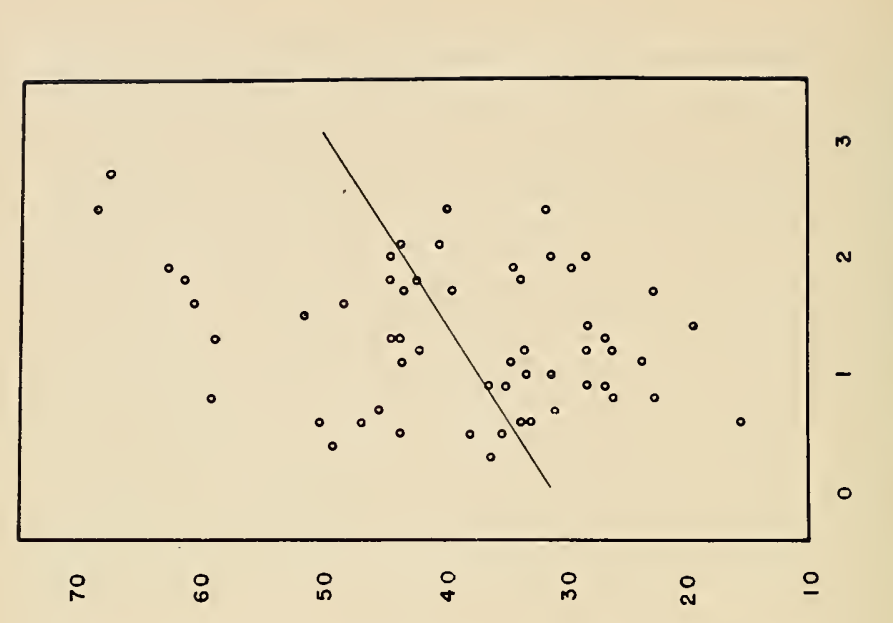

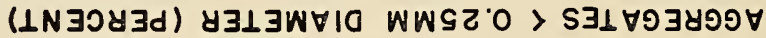

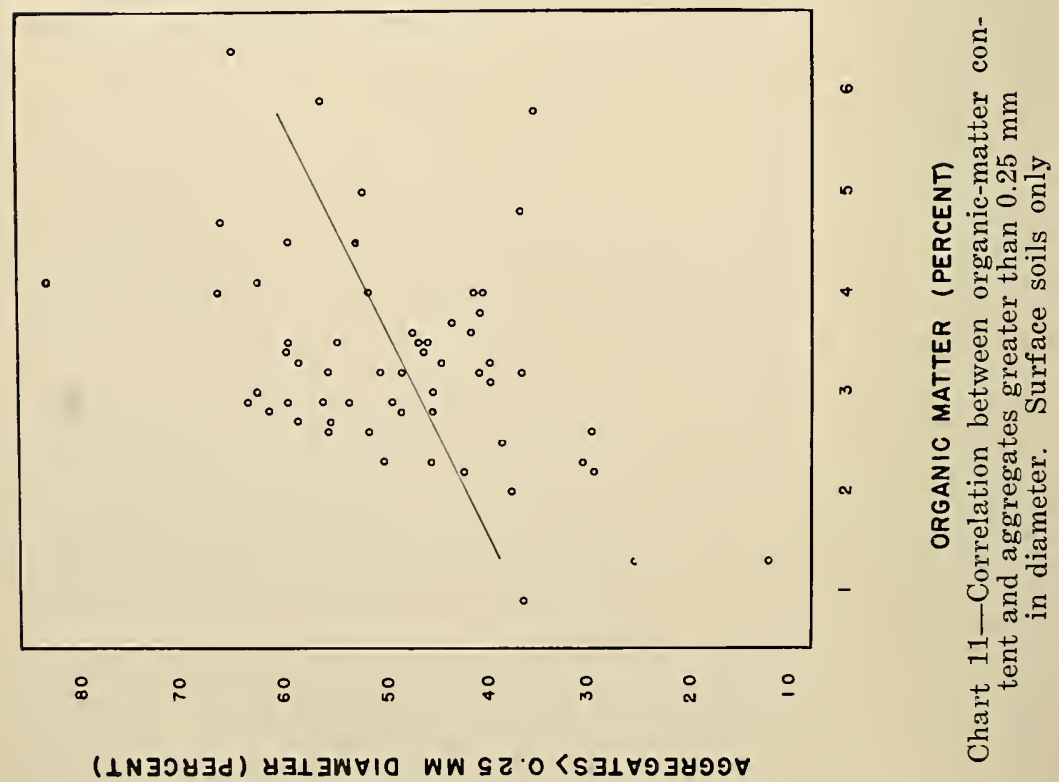




\section{Dispersion Ratio}

In soil technology the dispersion ratio is a measure of the ease with which the particles are brought into suspension. Other things being equal, a soil that is readily dispersed will be more susceptible to erosion than a soil more difficult to disperse.

The surface samples of the limestone soils have a mean dispersion ratio of 25.0 , which is significantly lower than 35.8 , the mean dispersion ratio of the sandstone and shale soils. Corresponding values for the subsoil are 35.4 and 45.4 . The lower mean dispersion ratio of the limestone soils may be explained on the basis of higher organic-matter content and of higher percentage of the fraction less than $0.05 \mathrm{~mm}$. A larger percentage of the fraction less than $0.05 \mathrm{~mm}$ is clay in the limestone than in the sandstone and shale soils.

On the basis of the data presented herein there is not a significant difference in the dispersion ratio of the cultivated and of the sodded sites, the mean values being 25.5 and 30.6 , respectively. A difference is logically to be expected, since the sodded sites are higher in their content of organic matter, which serves as a binding agent to cement the smaller particles into larger aggregates, thereby reducing the tendency for the particles to go into suspension. It is not surprising to find that these differences are not significant when there is so much variation within a cultural treatment for the individual soils. For example, extreme differences in the dispersion ratio of 26.4 and 63.6 were found in the cultivated sites of the Lehew soils and 25.8 and 79.1 in the cultivated sites of the Dekalb soils. As pointed out previously, some sites classified as cultivated have not been disturbed for several years and although they cannot be considered as being in permanent sod there are enough native grasses, and in some instances legumes, growing to have an appreciable effect upon the dispersion ratio. It was found on comparing the data obtained from sites selected as representative of permanent sod and of recent intensive tillage that the mean dispersion ratio of the sodded sites was significantly less than the mean dispersion ratio of the cultivated sites.

\section{Aggregation}

Limestone soils were found to be higher than sandstone and shale soils in the percentage of aggregates greater than $0.25 \mathrm{~mm}$ for both the surface and subsoil samples. This may be explained as due to the presence in the limestone soils of a larger amount of organic matter and clay, both of which are instrumental in binding the individual soil particles into largersized aggregates. 
Considering the effect of cultural treatment on aggregation, it is to be seen that surface samples from the sodded sites are more highly aggregated than are those from the cultivated sites. Organic matter and aggregation are positively correlated in both the surface and in the subsoils (Charts 11 and 12). Cultivation has materially reduced organic matter. The mechanical process involved in cultivation is also destructive to aggregates. Therefore it is logical that there be a less desirable structure in the intensively cultivated sites than in the sodded areas.

In Tables 1 and 2 aggregation is expressed by grouping together all aggregates greater than $0.25 \mathrm{~mm}$. Such a grouping does not take into consideration differences that may exist in the $2,1,0.5$, and $0.25 \mathrm{~mm}$ fractions and which have an influence on the water relationships of the soil. In order to present more clearly the effect of cultural treatment and vegetal cover on the distribution of the different-sized particles and aggregates, representative sodded and cultivated sites were selected; the data are presented graphically in Charts 13 and 14.

The effect of cultivating and disturbing the soil has been to increase the smaller-sized fractions at the expense of the larger-sized fractions, with the exception of the Lehew soil in which the values are essentially the same. In this latter case, a site in undisturbed sod adjacent to the cultivated site was not available, and a wooded area was selected instead. Consequently the soil sample used for determination of the aggregate analysis was taken immediately below the heavy protective covering of leaf litter. It is recognized that the soil structure, developed under sod, with its intricate network of fine roots, is different from that formed in wooded areas, where the number of small roots at the surface is generally somewhat less and where the accumulation of organic matter is largely at the immediate surface. The cultivated area was also found to contain 6.3 percent more particles greater than $0.25 \mathrm{~mm}$ in diameter-including fragments of shale- than did the wooded area; therefore the soil of the wooded area was actually the better aggregated.

The results for the subsoil samples were similar to those found in the surface, although the general trend is for the differences in the subsoil under sod and under cultivation to be somewhat less than in the surface soil. 

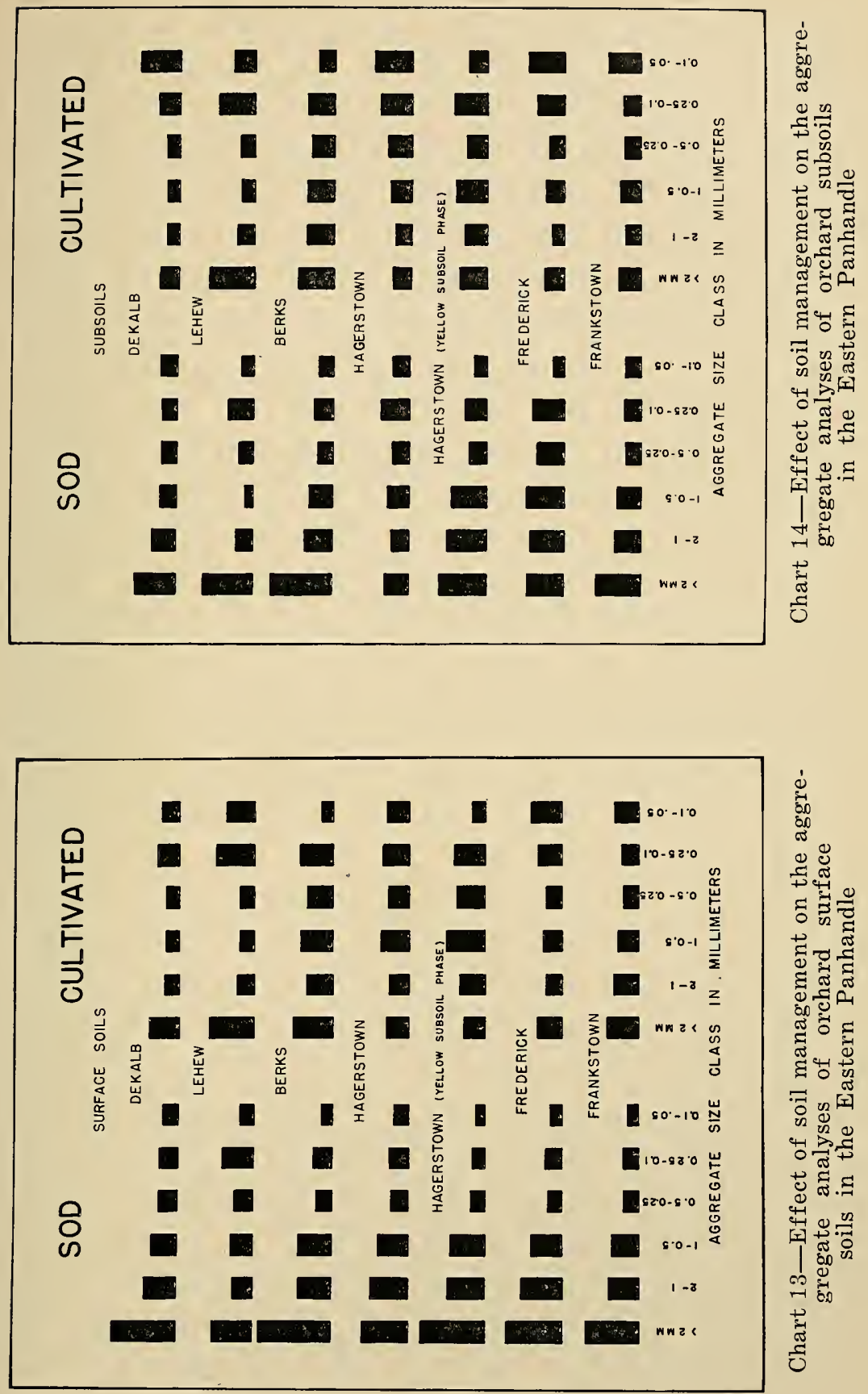
Tables 3 and 4 present the analysis of variance of several soil characteristics for 58 surface soils and for 56 subsoils, respectively.

Table 3-Analysis of Variance of Soil Characteristics For 58 Surface Soils

\begin{tabular}{|c|c|c|c|c|c|c|c|}
\hline \multirow{3}{*}{$\begin{array}{l}\text { Source of } \\
\text { variance }\end{array}$} & \multirow{3}{*}{$\begin{array}{l}\text { De- } \\
\text { grees } \\
\text { of } \\
\text { free- } \\
\text { dom }\end{array}$} & \multicolumn{6}{|c|}{ Mean square } \\
\hline & & \multirow{2}{*}{$\mid \begin{array}{c}\text { Moisture } \\
\text { equivalent }\end{array}$} & \multirow{2}{*}{$\begin{array}{l}\text { Organic } \\
\text { matter }\end{array}$} & \multirow{2}{*}{$\begin{array}{c}\text { Dispersion } \\
\text { ratio }\end{array}$} & \multirow{2}{*}{$\mid \begin{array}{c}\text { Aggre- } \\
\text { gates } \\
>0.25 \mathrm{~mm}\end{array}$} & \multicolumn{2}{|c|}{ Particles } \\
\hline & & & & & & $>0.25 \mathrm{~mm}$ & $<0.05 \mathrm{~mm}$ \\
\hline Origin & 1 & $69.88 * *$ & 1.95 & $1499.01 * *$ & $2676.43^{* * *}$ & $2563.94 * *$ & $4030.03^{* *}$ \\
\hline $\begin{array}{l}\text { Cultural treatment } \\
\text { Origin in cultural- }\end{array}$ & t 1 & $126.33^{* *}$ & $19.10^{* *}$ & 351.61 & $618.75^{* *}$ & 0.39 & 37.75 \\
\hline $\begin{array}{l}\text { treatment } \\
\text { interaction }\end{array}$ & 1 & 12.61 & 1.03 & 54.70 & 146.26 & 54.94 & 31.08 \\
\hline $\begin{array}{l}\text { Within subclasses } \\
\text { Total }\end{array}$ & $\begin{array}{l}54 \\
57\end{array}$ & 8.19 & 0.74 & 107.25 & 86.29 & 29.60 & 131.70 \\
\hline
\end{tabular}

**Highly significant.

Table 4-Analysis of Variance of Soil Characteristics For 56 Subsoils

\begin{tabular}{|c|c|c|c|c|c|c|c|c|}
\hline \multirow{3}{*}{$\begin{array}{l}\text { Source of } \\
\text { variance }\end{array}$} & \multirow{3}{*}{\multicolumn{2}{|c|}{$\begin{array}{c}\text { De- } \\
\text { grees } \\
\text { of } \\
\text { free- } \\
\text { dom }\end{array}$}} & \multicolumn{6}{|c|}{ Mean square } \\
\hline & & & \multirow{2}{*}{$\begin{array}{c}\text { Moisture } \\
\text { equivalent }\end{array}$} & \multirow{2}{*}{$\begin{array}{l}\text { Organic } \\
\text { matter }\end{array}$} & \multirow{2}{*}{$\begin{array}{c}\text { Dispersion } \\
\text { ratio }\end{array}$} & \multirow{2}{*}{$\begin{array}{l}\text { Agrre- } \\
\text { gate } \\
>0.25 \mathrm{~mm} \\
\end{array}$} & \multicolumn{2}{|c|}{ Particles } \\
\hline & & & & & & & $>0.25 \mathrm{~mm}$ & $<0.05 \mathrm{~mm}$ \\
\hline \multirow{3}{*}{\multicolumn{2}{|c|}{$\begin{array}{l}\text { Origin } \\
\text { Cultural treatment } \\
\text { Origin in cultural- } \\
\text { treatment }\end{array}$}} & 1 & $93.70 * *$ & $2.71 * *$ & $2273.01^{* *}$ & $1190.54 * *$ & $2052.57 * *$ & $3496.37 * *$ \\
\hline & & & 4.43 & $2.34 *$ & 23.59 & 21.57 & 74.07 & 10.83 \\
\hline & & & & & & & & \\
\hline \multirow{2}{*}{$\begin{array}{l}\text { interaction } \\
\text { Within subclasses } \\
\text { Total }\end{array}$} & & & 4.70 & 0.05 & 55.20 & 248.15 & $269.99 * *$ & 14.63 \\
\hline & & & 10.18 & 0.33 & 147.04 & 135.13 & 27.19 & 72.57 \\
\hline
\end{tabular}

*Significant.

**Highly significant. 


\section{SUPPLEMENTAL DATA ON THE EFFECT OF SOIL MANAGE- MENT ON CERTAIN SOIL PROPERTIES}

In addition to the data presented in Tables 1 and 2, volume weight, specific gravity, and infiltration rates were determined on selected soil samples. The total porosity was calculated from specific gravity and volume weight in the usual manner. The moisture equivalent has been shown to be a reasonably good measure of the field capacity of soils texturally silt loams $(7,24)$. The field capacity may also be taken as a value which is approximately the capillary porosity. The non-capillary porosity was calculated by subtracting the moisture equivalent on a volume basis from the total porosity. These data showing the effect of past cultural treatment and vegetal cover on certain physical characteristics of the surface and of the subsoil in typical orchards adjacent to each other are presented in Tables 5 and 6 , respectively.

The analyses of variance of the soil properties not considered previously are presented in Tables 7 and 8 for the surface and for the subsoil, respectively.

From these statistical data it is evident that the surface samples from the sodded sites have a lower volume weight, a higher total porosity, and a higher non-capillary porosity than the cultivated sites. There are no significant differences in the subsoil for any of the properties studied.

\section{Volume Weight}

The volume weight is generally considered as the weight of a unit volume of soil. It depends upon the texture, the specific gravity, the amount and type of the organic matter, and the compactness. Specific gravity is more or less constant for mineral soils. While textural differences occur among different soil types, with a specific type the sodded and cultivated sites do not differ materially. Therefore, variations in the volume weight in the sodded and in the cultivated areas are due largely to previous cultural treatments and to the vegetal cover.

The volume weight of these selected samples should not be considered as being necessarily representative of these soils in general; they are merely relative and not absolute. For example, there is no logical reason to expect a sodded area of Dekalb soil to have a volume weight of 0.97 and a Hagerstown soil treated similarly to have a volume weight of 1.26 , as shown 


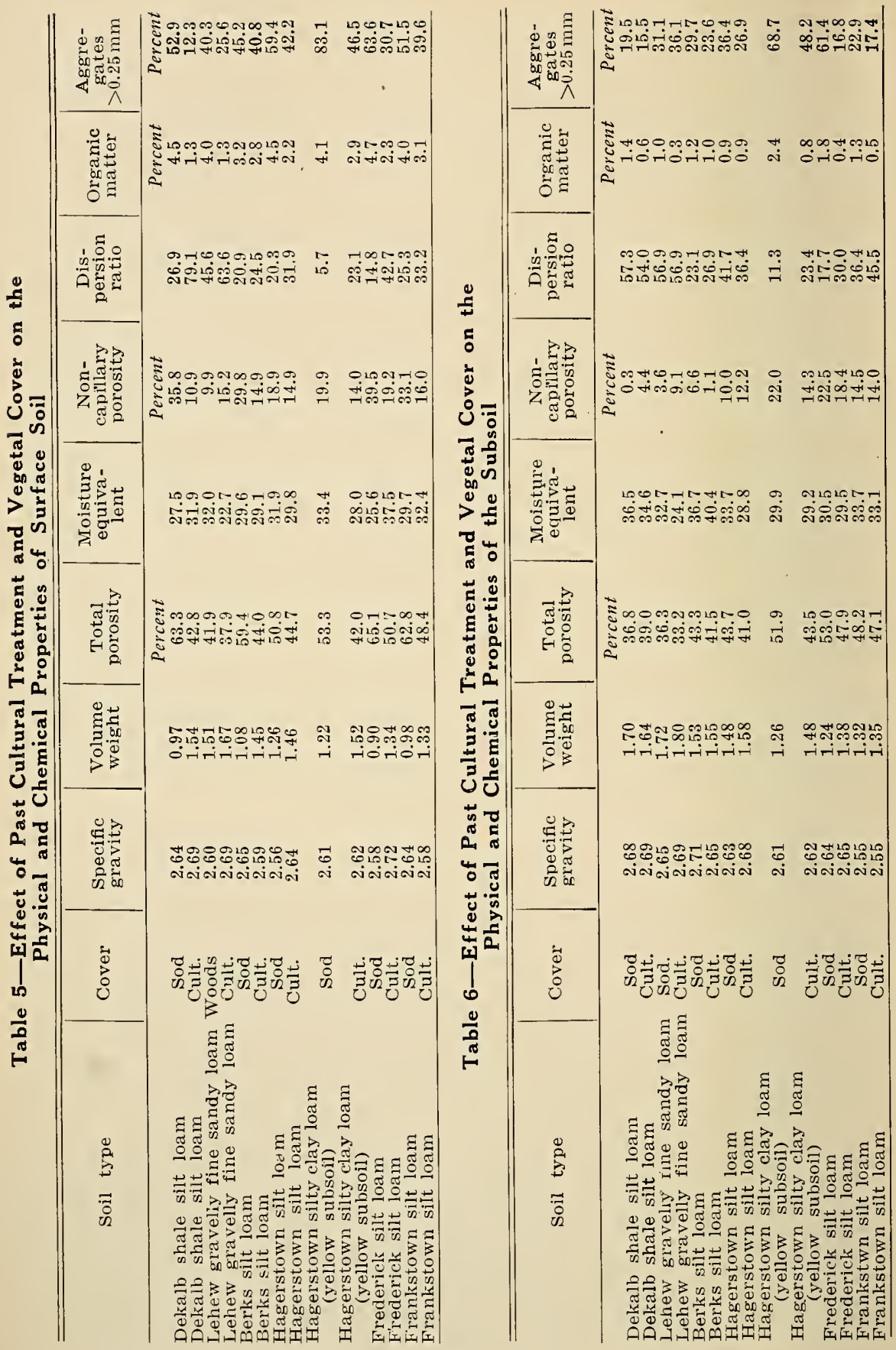


Table 7-Analysis of Variance of Soil Characteristics For 7 Surface Soils Selected on Basis of Cultural Treatment

\begin{tabular}{|c|c|c|c|c|c|}
\hline \multirow{2}{*}{ Source of variance } & \multirow{2}{*}{$\begin{array}{l}\text { Degrees } \\
\text { of } \\
\text { freedom }\end{array}$} & \multicolumn{4}{|c|}{ Mean square } \\
\hline & & $\begin{array}{l}\text { Specific } \\
\text { gravity }\end{array}$ & $\begin{array}{l}\text { Volume } \\
\text { weight }\end{array}$ & $\begin{array}{c}\text { Total } \\
\text { porosity }\end{array}$ & $\begin{array}{c}\text { Non-capillary } \\
\text { porosity }\end{array}$ \\
\hline $\begin{array}{l}\text { Discrepance } \\
\text { Soil type } \\
\text { Cultural treatment } \\
\text { Total }\end{array}$ & $\begin{array}{r}6 \\
6 \\
1 \\
13\end{array}$ & $\begin{array}{l}.29 \\
.12 \\
.45\end{array}$ & $\begin{array}{l}.01 \\
.05 \\
.41 * *\end{array}$ & $\begin{array}{c}16.16 \\
72.25 \\
529.56 * *\end{array}$ & $\begin{array}{c}55.99 \\
64.02 \\
476.78^{*}\end{array}$ \\
\hline
\end{tabular}

*Significant.

**Highly significant.

Table 8-Analysis of Variance of Soil Characteristics For 7 Subsoils Selected on Basis of Cultural Treatment

\begin{tabular}{|c|c|c|c|c|c|}
\hline \multirow{2}{*}{ Source of variance } & \multirow{2}{*}{$\begin{array}{l}\text { Degrees } \\
\text { of } \\
\text { freedom }\end{array}$} & \multicolumn{4}{|c|}{ Mean square } \\
\hline & & $\begin{array}{l}\text { Specific } \\
\text { gravity }\end{array}$ & $\begin{array}{l}\text { Volume } \\
\text { weight }\end{array}$ & $\begin{array}{c}\text { Total } \\
\text { porosity }\end{array}$ & $\begin{array}{c}\text { Non-capillary } \\
\text { porosity }\end{array}$ \\
\hline $\begin{array}{l}\text { Discrepance } \\
\text { Soil type } \\
\text { Cultural treatment } \\
\text { Total }\end{array}$ & $\begin{array}{r}6 \\
6 \\
1 \\
13\end{array}$ & $\begin{array}{l}.06 \\
.45^{*} \\
.03\end{array}$ & $\begin{array}{l}.02 \\
.04 \\
.02\end{array}$ & $\begin{array}{l}5.95 \\
63.75^{* *} \\
30.01\end{array}$ & $\begin{array}{r}91.22 \\
0.43 \\
126.41\end{array}$ \\
\hline
\end{tabular}

*Significant.

**Highly significant.

in the data. These data serve chiefly to emphasize the fact that, regardless of difference due to soil type, past cultural treatment and vegetal cover, both past and present, determine to a considerable extent the relative values of such soil properties as organic matter, aggregation, dispersion, volume weight, in= filtration rate, and losses of soil and water due to run-off.

\section{Porosity}

The pore space in soils has been said commonly to consist of (1) pores of capillary dimension, through which water can pass only under tension, and (2) non-capillary pores, which are larger and through which water can move more or less freely under gravitational forces. High non-capillary porosities have been shown to be associated with high rates of infiltration (12). With the specific gravity remaining essentially constant, changes in volume weight are accompanied by corresponding changes in total porosity. In general, a high total porosity is associated with a high non-capillary porosity, but this is not universally true. For example, a poorly aggregated clay soil may have a high total porosity and be essentially void of pores large enough to be considered of non-capillary dimensions.

On the basis of these data, surface samples from sodded sites have a lower volume weight, a higher total porosity, and a higher non-capillary porosity than the cultivated soils. In 
the subsoil a significant difference due to soil type was found both in specific gravity and in total porosity. There were no significant differences due to cultural treatments for these subsoil characteristics.

\section{Infiltration Rates}

The effects of vegetal cover, tillage, and mulching on the inflitration rates were studied on a few areas. In Table 9 is shown the effect of tillage on the infiltration rate of the Lehew, Dekalb, Berks, Hagerstown, and Frankstown soils. The sites selected for the study have received some cultivation in the past, consisting of several diskings every season for various and $\mathrm{un}_{\bar{i}}$ certain numbers of years. In recent times, this practice has been discontinued generally, and volunteer native vegetation has been allowed to grow. The amount and the type of cover at present are quite variable, depending upon the soil series and upon the previous soil treatment. In most cases relatively good numbers of soil-protecting plants are present.

Table 9-Effect of Cultivation and Mulching on the Infiltration Rate

\begin{tabular}{l|c|c|c}
\hline \multirow{2}{*}{ Soil type } & \multicolumn{3}{|c|}{ Infiltration rate, inches per hour } \\
\cline { 2 - 4 } & & $\begin{array}{c}\text { Cultivated } \\
\text { Cultivated } \\
\text { in past }\end{array}$ & $\begin{array}{c}\text { Cultivated } \\
\text { 3 inches deep } \\
\text { and mulched } \\
\text { recently } \\
\text { recently* }\end{array}$ \\
\hline Dekalb shale silt loam & 1.75 & 0.16 & $\mathbf{2 . 2 0}$ \\
Hagerstown silt loam & 0.67 & 0.59 & $\mathbf{1 . 8 0}$ \\
Frankstown silt loam & 1.18 & 0.24 & - \\
Berks silt loam (shallow phase) & 0.06 & 0.06 & - \\
Lehew gravelly fine sandy loam & 1.31 & 0.49 & \\
\hline
\end{tabular}

*Immediately before determining the infiltration rate.

Before the infiltration rate was determined with a North Fork infiltrometer, the vegetation present was removed by close clipping in all instances, and on each of the five series, one site was cultivated to a depth of 3 inches with a hoe. As Table 9 shows, cultivation of the surface 3 inches has decreased the infiltration rate in inches per hour from 1.31 to 0.49 in the Lehew, 1.75 to 0.16 in the Dekalb, 0.67 to 0.59 in the Hagerstown, and 1.18 to 0.24 in the Frankstown soil, while the Berks soil has remained unaffected by cultivation.

The effect of mulching with a 11/2-inch layer of wheat straw after an initial 3-inch cultivation on the Dekalb, Hagerstown, and Frankstown soils is shown in Table 9. Sites were employed adjacent to the areas which had been used to study the effect of tillage on the infiltration rate. After cultivating the soil to a depth of 3 inches, a straw mulch was applied and the soil was brought to the field capacity. The infiltration rates in inches per hour for the cultivated and for the cultivated and mulched sites, respectively, were 0.16 and 2.20 in the Dekalb, 
0.59 and 1.80 in the Hagerstown, and 0.24 and 1.18 in the Frankstown. As shown in Table 9, it is evident that when clean tillage is practiced, especially when the ground is dry enough to encourage dust mulch formation and a heavy rain follows, the dispersing action of the large raindrops soon seals many of the surface pores. The result is that a large part of the water runs off, causing serious loss of soil and contributing little to the soil moisture available to the trees. A similar reaction may occur after the seeding of cover crops before they can offer protection against erosion. It is evident that mulching has increased the infiltration rate over that of the uncultivated soil, while cultivation has materially reduced it. The purely physical effect of mulching is to eliminate the violent dispersing action of the large raindrops as they strike the ground. Consequently, as the protected surface layer of the soil remains loose and open, this condition is conducive to rapid intake of water.

Table 10 shows the effect of previous orchard-soil management on the infiltration rate for the Lehew, Dekalb, Berks, Hagerstown, Frankstown, and Frederick soils. The type and the amount of cover in the sodded areas are somewhat variable, but in general there are represented portions of orchards which have been subjected to no disturbance for many years. The infiltration sites were selected either between the trees and completely out of the roadways used in orchard operations or on relatively undisturbed protected areas adjoining the orchard. There has been little or no soil compaction by spray rigs or by other heavy mobile weights; the cover has either been clipped and allowed to lie or else it has grown up, died, and fallen back on the ground. In this manner there has been a surface accumulation of organic material and a building up of a loose layer of surface soil. This largely explains the rapid infiltration rate for all of the sodded sites except the Berks. The maximum infiltration rates of the soils other than the Berks could not be determined, since the largest nozzles available for the infiltrometer gave a maximum rate of about 5.0 inches per hour.

Table 10-Effect of Soil Management on the Infiltration Rate

\begin{tabular}{|c|c|c|}
\hline \multirow{2}{*}{ Soil type } & \multicolumn{2}{|c|}{ Infiltration rate, inches per hour } \\
\hline & $\begin{array}{c}\text { Undisturbed } \\
\text { sod }\end{array}$ & $\begin{array}{l}\text { Cultivated } \\
\text { in past }\end{array}$ \\
\hline $\begin{array}{l}\text { Lehew gravelly fine sandy loam } \\
\text { Dekalb shale silt loam } \\
\text { Berks silt loam (shallow phase) } \\
\text { Hagerstown silt loam } \\
\text { Frankstown silt loam } \\
\text { Frederick silt loam }\end{array}$ & $\begin{array}{l}5.00+ \\
5.00+ \\
0.06 \\
5.00+ \\
5.00+ \\
5.00+\end{array}$ & $\begin{array}{l}1.31 \\
1.75 \\
0.16 \\
0.67 \\
0.66 \\
0.49\end{array}$ \\
\hline
\end{tabular}


Sod has not increased the infiltration rate of the Berks over that of the cultivated area. The soil in this orchard was mapped as a silt loam; it had a shallow surface underlain by a compact subsoil which graded into undifferentiated parent material at a depth of 12 to 15 inches. Until the limited pore space was filled with water, the infiltration rate was relatively high. However, when once saturated, the compactness of the subsoil limited the downward movement of water, and the infiltration rate approached zero regardless of the surface treatment or cover.

The high infiltration rates of the other sods to which reference is made in this study should not be confused in any way with those of otherwise comparable areas which have been pastured, for entirely different conditions exist in pastures. In such places, vegetal material has not been allowed to accumulate, and tramping by the animals has compacted the soil. This accounts, in part, for the relatively low infiltration rates of some pasture fields observed by the senior author. It was observed that there was appreciable lateral movement of water in the extremely loose well-sodded sites, even though the area adjacent to the rain pan was at the field capacity. Consequently the infiltration rates by this method on these sites are probably higher than under ordinary conditions where the water is distributed more or less uniformly over the soil surface. Irrespective of this possibility, the data serve to show that undisturbed sodded areas, not subject to compaction and on which the plant residues are allowed to accumulate, will over a period of time develop a loose, mellow surface-layer conducive to the maximum absorption of water.

\section{Available Moisture}

It is evident from Charts 1 to 10 , inclusive, that the vertical distribution of the roots of apple trees in the Eastern Panhandle is limited by the depth of the soil. Trees on the shallower soils, such as the Dekalb, Berks, and Lehew, are much more susceptible to drouth (Figs. 2, 4, 5, 6) and generally to nutritional deficiencies than are trees on the deeper Hagerstown, Frankstown, and Frederick soils (Fig. 9). In order to obtain more specific information regarding the moisture relationships, including the available moisture of certain of these soils, data were obtained as shown in Table 11 .

As has been mentioned previously, the moisture equivalent has been shown to be a reasonably good measure of the field capacity particularly in silt-loam soils. The field capacity has generally been considered as the water-retaining capacity of a soil one to five days after a heavy rain or after an application 
Table 11 -Amount of Available Moisture in Certain Orchard Soils of the Eastern Panhandle ${ }^{1}$

\begin{tabular}{|c|c|c|c|c|c|c|}
\hline \multirow[b]{2}{*}{ Soil } & \multirow{2}{*}{$\begin{array}{l}\text { Depth } \\
\text { sampled }\end{array}$} & \multirow{2}{*}{$\begin{array}{l}\text { Moisture } \\
\text { equivalent }\end{array}$} & \multicolumn{2}{|c|}{ Wilting coefficient } & \multicolumn{2}{|c|}{ Available moisture } \\
\hline & & & M. C. $/ 1.84$ & Sunflower & M. C. $/ 1.84$ & Sunflower \\
\hline $\begin{array}{l}\text { Hagerstown } \\
\text { silt loam }\end{array}$ & $\begin{array}{c}0-5 \\
5-12 \\
12-36\end{array}$ & $\begin{array}{l}28.3 \\
25.3 \\
34.2\end{array}$ & $\begin{array}{l}15.3 \\
13.7 \\
18.6\end{array}$ & $\begin{array}{r}8.1 \\
8.9 \\
21.2\end{array}$ & $\begin{array}{l}13.0 \\
11.6 \\
15.6\end{array}$ & $\begin{array}{l}20.2 \\
16.4 \\
13.0\end{array}$ \\
\hline $\begin{array}{l}\text { Berks shale } \\
\text { silt loam }\end{array}$ & $\begin{array}{l}0-7 \\
7-15\end{array}$ & $\begin{array}{l}29.1 \\
25.3\end{array}$ & $\begin{array}{l}15.8 \\
13.7\end{array}$ & $\begin{array}{l}9.0 \\
8.5\end{array}$ & $\begin{array}{l}13.3 \\
11.6\end{array}$ & $\begin{array}{l}20.1 \\
16.8\end{array}$ \\
\hline $\begin{array}{l}\text { Frankstown } \\
\text { silt loam }\end{array}$ & $\begin{array}{c}0-7 \\
7-14 \\
14-32\end{array}$ & $\begin{array}{l}25.8 \\
24.8 \\
24.2\end{array}$ & $\begin{array}{l}14.0 \\
13.5 \\
13.1\end{array}$ & $\begin{array}{l}6.6 \\
7.5 \\
9.8\end{array}$ & $\begin{array}{l}11.8 \\
11.3 \\
11.1\end{array}$ & $\begin{array}{l}19.2 \\
17.3 \\
14.4\end{array}$ \\
\hline
\end{tabular}

1These data were collected by L. P. Batjer, formerly Assistant Horticulturist, West Virginia Agrícultural Experiment Station.

of irrigation water. The moisture content of a soil when plants permanently wilt is the wilting coefficient. Therefore, the difference in moisture between the moisture equivalent and the wilting coefficient may be considered as representing approximately the available moisture in soils.

Two methods were used for arriving at the wilting coefficient.* The first one was that of dividing the moisture equivalent by the factor 1.84, as suggested by Briggs and Shantz (5). However, it has been found by numerous workers that the factor 1.84 varies widely with different soils and that the method at best can be considered to yield only an approximate value. Secondly, the sunflower method (5) for determining the wilting coefficient was used on a limited number of samples. The determinations were made in quadruplicate or in quintuplicate on each sample. While this method also has its limitations, it is believed by many investigators to be a more accurate measure of the true wilting coefficient than is the moisture equivalent divided by an average factor. From the data in Table 5 it is evident that there is considerable variation in the results obtained by the two methods for determining available water. In this particular study the sunflower method gives in general somewhat lower values than the arbitrary calculation of the moisture-equivalent factor.

Although the percentage of available moisture is essentially the same for the soils included in this study, there still exists a large difference in the total amount of moisture available to the trees in the Berks and the Hagerstown soil; this is due to the large difference in the total volume of soil reached by

*Wilting coefficient data reported herein were obtained by L. P. Batjer, formerly Assistant Horticulturist, West Virginia Agricultural Experiment Station. 
the roots. For example, Chart 1 shows that practically all of the roots in the Berks shale loam are in the surface 12-15 inches, while the roots in the Hagerstown silt loam (Chart 9) may extend to a depth of more than 9 feet. If one assumes that both soils were at the field capacity as represented by the moisture equivalent, then the amount of moisture available to the plants would be approximately 2.6 inches in the Berks and at least 14.5 inches in the Hagerstown soils. For that reason, the Berks soils, unless replenished by frequent rains, will not supply enough moisture for maximum production except in growing seasons in which the normal amount of rainfall is well distributed. In severe drouth years, the water supply may be so reduced that the wilting point is reached and the trees either are killed outright (Fig. 3) or else are injured severely. Furthermore, as shown in Table 9 the infiltration rates are so low that, when heavy rains occur, most of the water is lost as run-off, once the shallow profile is saturated, even if the surface is protected by a good cover of growing vegetation or by a mulch. In the deeper limestone soils, the potential supply of moisture is so much greater than in the shallow soils that even during drouth periods the trees, through their deeper root systems, which exploit greater volumes of soil, are able to obtain water at greater depths and consequently are not so liable to severe damage.

Throughout the soil profile, the relation of capillary to noncapillary porosity and to soil volume has a very important influence on physical characteristics of the soil, such as aeration, permeability, and water-holding properties. In order to present more clearly the pore space relationships of the soils included in this study, data from typical profiles are presented graphically in Charts 15 and 16.

A number of important points are to be seen in this figure. The sandstone- and shale-derived soils, the Dekalb, Berks, and Lehew, are much shallower than the limestone-derived soils, the Hagerstown, Hagerstown (yellow subsoil phase), Frankstown, and Frederick. The non-capillary porosity decreases rapidly in the sandstone and shale soils. In the Hagerstown (yellow subsoil phase), the non-capillary porosity falls off quickly below the 9-12 inch layer, whereas the Hagerstown silt-loam soil maintains a relative high non-capillary porosity throughout the soil profile. The water relationships in these soils are recognized as being widely different. The Hagerstown silty clay loam (yellow subsoil phase) is relatively impermeable and drains with difficulty, while the Hagerstown silt loam is well drained. 

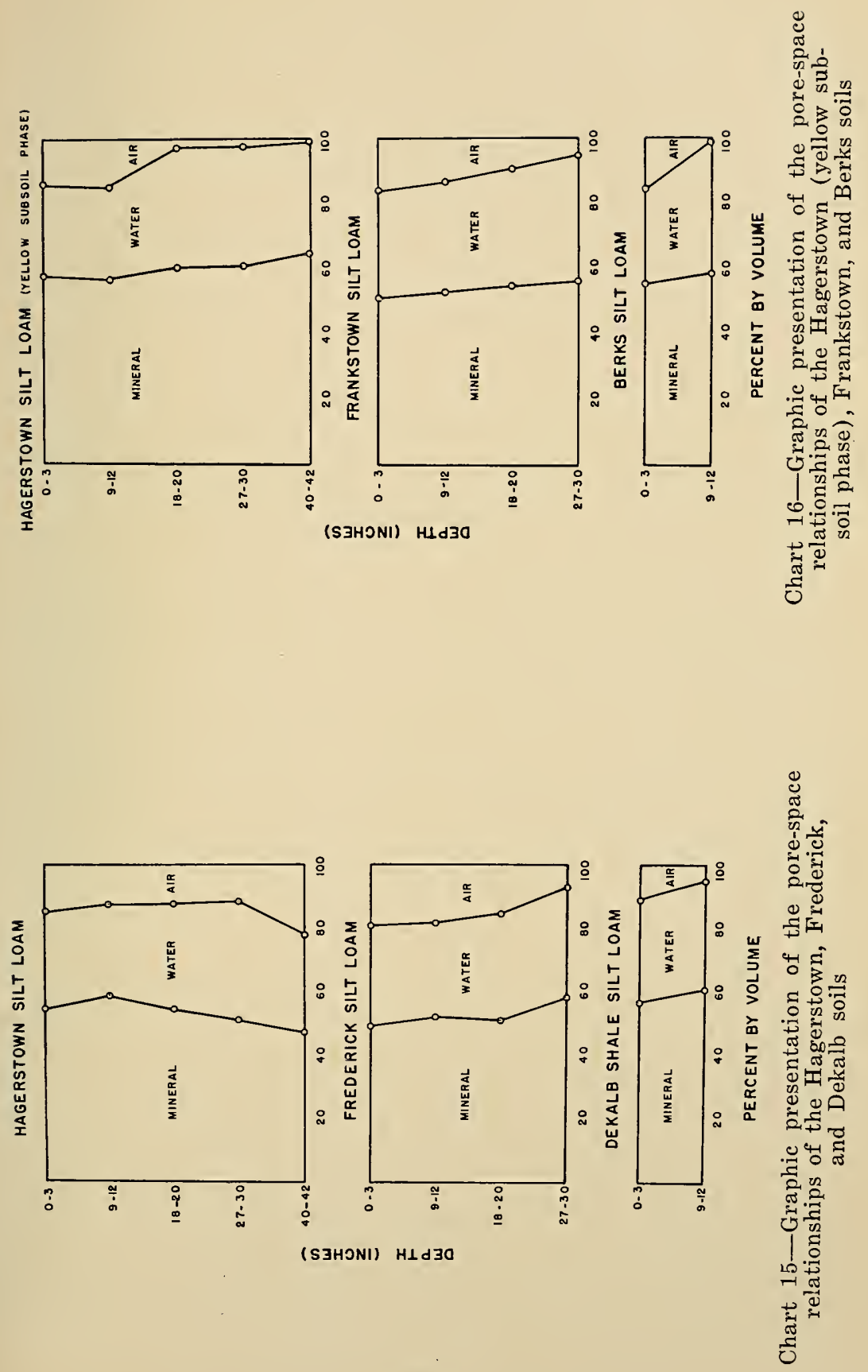
In general, from these data it is evident that much can be accomplished with regard to the conservation of water and soil in orchards by following certain soil-management practices. Previous cultural treatments, especially if intensive and long continued, have a very important effect upon the physical and the chemical properties of the soil. If a soil is allowed to remain in an undisturbed sod, a desirable soil structure which is conducive to the rapid absorption of water and to little, if any, soil erosion is built up or maintained. On the other hand, cultivation tends to deplete the organic-matter content, to increase the percentage of the smaller-sized aggregates at the expense of the larger-sized ones, and in general to leave the soil in a physical condition which is conducive to rapid losses of soil and water.

If the soil is cultivated, the securing of the heaviest practical growth of cover crops, the incorporation of organic residues from outside sources whenever possible, or the adoption of a sod rotation, including both legumes and a close-growing type of vegetation, will help maintain a desirable structural condition.

Moisture is often a limiting factor in orchards in the Cumberland-Shenandoah Region, especially during certain critical periods of the growing season. Water lost as run-off from intense summer rains falling on unprotected areas can be avoided, or reduced to a large extent, by adopting a system of orchard cultural management in which a minimum of soil disturbance occurs and in which an adequate soil cover is provided throughout the year to protect the surface from the dispersing action of rain. Contour planting, terracing, and diversion ditches should be considered also as supplemental practices for all proposed plantings. 


\section{GENERAL DISCUSSION}

An orchard requires the expenditure of both a large amount of money and a number of years before any return on the investment is realized. From a production standpoint, the degree of success of any orchard is dependent upon the integration of a large number of interrelated factors. The orchardist who is most likely to be successful will take into consideration all known factors, eliminating in so far as possible those which have proved hazardous and in addition making the best possible use of the more desirable yet economical practices of orchard management.

The type of soil is a very important consideration either from the standpoint of starting a new orchard or from that of the operation of an established orchard. Weathering processes acting on the parent material over a long period of time have developed the soils as they are found today. From a practical standpoint, there is nothing that can be done to change the texture and depths of soils in the field. Proper methods of orchard-soil management are helpful but these will not overcome the inherent limitations of soil depth. It is evident from the root distribution charts that the depth of the soil limits effectually the depth of root penetration. A limited root system also limits the potential supply of water and mineral nutrients, both of which are necessary in sufficient amounts, at the proper times, if the desired production is to be obtained. While most of the shallow soils derived from sandstone and shale have definite limitations because of potential injury to trees and crops from drouth, they do have certain advantages in a lower overhead, including the initial cost of the land, the interest on investment, taxes, and in general less danger of damage from spring frost, than the lower-lying but much more fertile limestone soils. While some few commercial apple and peach orchards are being operated with a fair degree of success on the relatively shallow shale and sandstone soils, the location of new orchards cannot be generally recommended on any other than the superior and deeper phases of these soils, and then it should be realized that the hazards of drouth are relatively much greater than on the deeper soils and that good soil-management practices, including water conservation, must be exercised if any consistent degree of success is to be obtained.

Soil management is also a very important consideration either from the standpoint of starting a new orchard or from that of the operation of an established orchard. It is evident that the soil in apple orchards in continuous sod has developed or maintained a favorable structural condition which is con- 
ducive to the rapid absorption of water and to the minimum loss of soil. Likewise, fertility has been maintained, since losses by erosion have been largely eliminated and the vegetation growing on the ground has been clipped and allowed to fall on the ground to help maintain the supply of organic matter. Likewise, the root development of the ground cover, when undisturbed by cultivation, has also been very instrumental in maintaining a favorable soil structure. In marked contrast, tillage has had the opposite effect in that biological activity has been increased temporarily; consequently the organic matter content has been depleted. As the organic matter content decreases, some of the larger-sized aggregates are broken down into smaller-sized aggregates; and the longer and the more intensive the cultivation, the greater the effect. The ease of dispersion of the soil aggregates is increased. Under uniform conditions, a soil more easily dispersed will be subject to larger losses not only because of the larger amount of suspended material but also because of the larger amount of run-off, as a result of the surface pores of the soil becoming clogged with the fine material filtered out of the infiltration water. By decreasing the effective size of the aggregates and hence by bringing about an undesirable closer space arrangement of the soil particles and aggregates, the ratio of non-capillary to capillary pores will be decreased as well as the size of the remaining capillary pores. The non-capillary porosity is an extremely important factor in determining the amount and rate of infiltration of water into and through the soil by force of gravity. Soils low in non-capillary porosity will in general have a low infiltration rate. Increasing the infiltration rate of a soil has the desirable effect of reducing the amount of run-off which occurs, therefore decreasing the loss of soil.

Mulches may be used to advantage when the surface is not or cannot be protected by some type of vegetative cover. In peach orchards of the Eastern Panhandle, clean tillage with inadequate cover crops is still a common practice. When properly utilized, cover crops are extremely helpful in reducing the loss of soil and water by run-off and by the removal of nutrient materials by leaching. The advantages of using a mulch lie in the protection it affords by decreasing the mechanical losses of the soil and by increasing the intake of water. Likewise, losses of moisture by evaporation are reduced and weeds and other vegetation are controlled which otherwise would compete with the trees for the moisture. The physical objections to mulching have been that the control of insects and mice is more difficult. However, modern methods have now largely eliminated these objections. The cost of mulching material and 
its scarcity and difficulty of production in certain areas, regardless of price, are effective, practical reasons why it can never be utilized economically as much as its effectiveness would justify.

In general the protection of the soil surface with a good vegetative cover, such as legume sods, native grasses, or cover crops, or else by adequate mulching, requires the utilization of good orchard-soil-management practices. So far as is economically possible these practices should be encouraged as they all improve the physical and the chemical properties of the soil, increase the intake of water, and decrease the losses of soil. Whatever one or combination is required in a particular instance will vary with the attendant conditions. Likewise, the planting of new orchards on the contour and the adoption of contour tillage and other conservation measures in established orchards wherever possible are also desirable practices, all of which are of vital importance for more nearly permanently successful orcharding. 


\section{SUMMARY AND CONCLUSIONS}

The results of this study of certain soil factors affecting the commercial apple production in the Eastern Panhandle of West Virginia may be summarized as follows:

The vertical root distribution is limited almost entirely by the depth of the soil. In the shallow soils derived from sandstone and shale the roots are limited on the average to depths of less than four feet, whereas in the deeper limestone soils roots penetrated to a depth of nine feet or more.

The soil is a very important consideration either from the standpoint of setting a new orchard or from that of the operation of an established orchard. A few commercial apple and peach orchards are being operated with a fair degree of success on the relatively shallow sandstone and shale soils. However, the location of new orchards cannot be generally recommended on any other than the deeper phases of the shallow soils derived from sandstone and shale, and then good soil management should be exercised.

Compared with an undisturbed sod, cultivation has reduced materially the organic-matter content, the percentage of the larger-sized aggregates, the non-capillary porosity, and the infiltration rate; it has increased volume weight and the dispersion ratio.

The soils derived from limestones were higher in moisture equivalents, organic-matter contents, aggregates greater than $0.25 \mathrm{~mm}$, particles less than $0.05 \mathrm{~mm}$, and lower in dispersion ratios and in particles greater than $0.25 \mathrm{~mm}$ than were the soils derived from sandstone and shale; the only exception is that of the organic-matter content in the subsoils, which is not significantly different.

In general, the data emphasize the importance of organic mulches or adequate vegetal cover to protect the surface soil from the beating action of rain which brings the soil particles into suspension either to be lost as run-off or to clog the surface pores, in either case increasing the losses of soil and water. Orchards which have been in sod continuously have thereby automatically maintained structural conditions conducive to the rapid infiltration of water with little, if any, loss of soil. In marked contrast, cultivation tends to deplete the fertility of the soil and it is also destructive of its desirable physical properties, thus increasing the susceptibility of the orchard site to losses of water and of soil and the liability of the trees to injury by drouth. 


\section{LITERATURE CITED}

( 1) Alexander, L. T., Byers, H. G., and Edington, Glen. A chemical study of some soils derived from limestone. U. S. Dept. of Agr. Tech. Bul. No. 378, 1939.

( 2) Baver, L. D. Aggregation of desert soils. Amer. Soil Survey Assoc. $16: 54-55,1935$.

( 3) Factors contributing to genesis of soil microstructure. Amer. Soil Survey Assoc. Bul. 16:55-56, 1935.

(4) Briggs, L. J., and McLane, J. W. The moisture equivalent of soil. U. S. Dept. of Agr. Bur. Soils, Bul. 45:1-23, 1907.

( 5) and Shantz, H. L. The wilting coefficient for different plants and its indirect determination. U. S. Dept. of Agr. Bur. Plant Ind. Bul. 230, 1912.

(6) Browning, G. M. Changes in erodibility of soils brought about by application of organic matter. Soil Sci. Soc. Amer. Proc. $2: 85-96,1937$.

(7) The relation of the field capacity to the moisture equivalent in soils of West Virginia. Soil Sci. 52:445-450, 1941.

( 8) - A comparison of the dry combustion and the rapid titration methods for determining organic matter in soil. Soil Sci. Soc. Amer. Proc. 3:158-161, 1938.

( 9 ) Corbett, L. C. Apple districts of West Virginia. W. Va. Agr. Exp. Sta. Bul. 75, 1901.

(10) Davis, W. C. Peach growing in West Virginia. W. Va. Agr. Exp. Sta. Bul. 82, p. 425, 1902.

(11) Duley, F. L., and Russell, J. C. The use of crop residues for soil and moisture conservation. Jour. Amer. Soc. Agron. 31:703-709, 1939.

(12) Free, G. R., Browning, G. M., and Musgrave, G. W. Relative infiltration and related physical characteristics of certain soils. U. S. Dept. Agr. Tech. Bul. No. 729, 1940.

(13) Goldbeck, A. T., and Jackson, F. H. Tests and soils with relation to their use in subgrades of highways. Proc. Amer. Soc. Test. Mat. 21:1057-1072, 1921.

(14) Hillebrand, W. F. The analysis of silicate and carbonate rocks. U. S. Geol. Survey Bul. 700, 1919.

(15) Middleton, H. E. Properties of soils which influence erosion. U. S. Dept. Agr. Tech. Bul. 178, 1930.

(16) Olmstead, L. B., Alexander, Lyle T., and Middleton, H. E. A pipette method of mechanical analysis of soils, based on improved dispersion procedure. U. S. Dept. Agr. Tech. Bul. 170, 1930.

(17) Paschal, A. H., Burke, R., and Baver, L. D. Aggregation studies on Muskingum, Chester, Lansdale silt loams. Amer. Soil Survey Assoc. Bul. 16:44-45, 1935.

(18) Rowe, P. B. The construction, operation and use of the North Fork infiltrometer. U. S. Flood Control Coordinating Comm. Misc. Publ. No. 1, 1940. 
(19) Schollenberger, C. J. A rapid approximate method for determining soil organic matter. Soil Sci. 24:65-68, 1937.

(20) —Determination of soil organic matter. Soil Sci. 31:483-486, 1931.

(21) Shaulis, N. J., and Merkle, F. G. Some effects on the soil of different orchard soil management practices. Pa. Agr. Exp. Sta. Bul. 373, 1939.

(22) Stauffer, R. S. Influence of soil management on some physical propperties of a soil. Jour. Amer. Soc. Agron. 28:900-906, 1936.

(23) Veihmeyer, F. J. An improved soil-sampling tube. Soil Sci. 27:147$152,1929$.

(24) and Hendrickson, H. H. The moisture equivalent as a measure of the field capacity of soils. Soil Sci. 32:181-193, 1931.

(25) Wakley, A., and Black, I. Armstrong. An examination of the Degtjareff method for determining soil organic matter, and a proposed modification of the chromic acid titration method. Soil Sci. $37: 29-38,1934$.

(26) Yoder, Robert E. A direct method of aggregate analysis of soils and a study of the physical nature of erosion losses. Jour. Amer. Soc. Agron. 28:337-351, 1936. 





